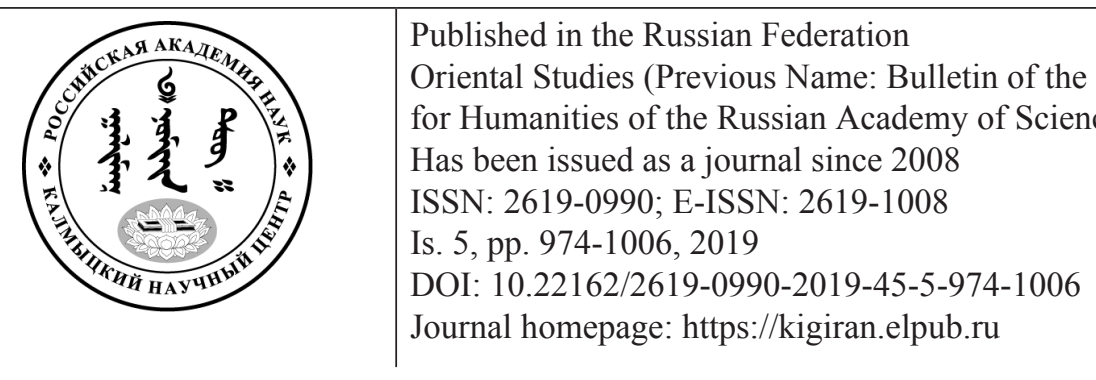

УДК 81

\title{
Структурные схемы монгольских аналитических конструкций в количественном аспекте
}

\author{
Сергей Александрович Крылов 1
}

\author{
${ }^{1}$ Институт востоковедения РАН (д. 12, ул. Рождественка, 107031 Москва, Российская Федерация) \\ доктор филологических наук, ведущий научный сотрудник \\ ORCID: 0000-0001-52070949. E-mail: krylov-58@mail.ru
}

\begin{abstract}
Аннотация. В работе сделана попытка структурной классификации аналитических словоформ (= «аналитических конструкций», АК) монгольского языка в количественном аспекте. Эвристически наиболее плодотворным признаётся «широкий» подход к АК, представленный в так называемой теории «грамматикализации» или «грамматизации», но этот подход должен быть дополнен количественными методами, разработанными в корпусной лингвистике. Подсчёт делался на материале Генерального корпуса монгольского языка. На его материале изучены наиболее употребительные структурные классы АК монгольского языка. АК представлены в прямом алфавитном порядке синтетических грамматем, входящих в аналитические грамматемы, а внутри него - в прямом алфавитном порядке аналитических структурных схем, а уже внутри этого порядка - в ранговом поряке убывания частот. Приведены наиболее употребительные АК, абсолютная частотность которых превышает 10 вхождений, а относительная - 9 ipm. Таких АК в корпусе ГКМЯ-1а насчитывается 1818.
\end{abstract}

Ключевые слова: монгольский язык, корпусная лингвистика, количественные методы в лингвистике, аналитические конструкции, аналитические формы

Благодарность. Настоящее исследование выполнено при поддержке комплексной программы фундаментальных исследований ОИФН РАН «Евразийское наследие и его современные смыслы» направление «Создание версии «3» генерального корпуса современного монгольского языка»), а также РФФИ (грант № 18-012-00611 «Структурно-вероятностная морфология монгольских языков» и № 19-512-44017 «Структурно-вероятностная интегральная модель монгольских языков»).

Для цитирования: Крылов С. А. Структурные схемы монгольских аналитических конструкций в количественном аспекте. Oriental Studies. 2019;(5): 974-1006. DOI: 10.22162/2619-09902019-45-5-974-1006. 
UDC 81

\title{
Structural Diagrams of Mongolian Analytical Constructions in a Quantitative Aspect
}

\author{
Sergei A. Krylov ${ }^{I}$ \\ ${ }^{1}$ Institute of Oriental Studies of the RAS (12, Rozhdestvenka St., Moscow 107031, Russian Federation) \\ Dr. Sc. (Philology), Leading Research Associate \\ ORCID: 0000-0001-52070949.E-mail: krylov-58@mail.ru
}

\begin{abstract}
Goals. The work attempts to structurally classify Mongolian analytical word forms ('analytical constructions') in a quantitative aspect. Materials and Methods. Heuristically, it is the 'wide' approach to analytical constructions represented in the so called 'grammaticalization' or 'grammatization' theory which is viewed as the most efficient one, but it must also be supplemented with quantitative methods developed by corpus linguistics. The paper analyzes materials contained in the General Corpus of the Mongolian Language and, namely, some most widely used structural classes of Mongolian analytical constructions. Results. The analytical constructions are arranged in alphabetical order of synthetical grammatemes included in analytical grammatemes, and inside the structure - in direct alphabetical order of structural analytical diagrams, and further - in order of frequency. The paper lists most widely used analytical contructions with absolute frequencies over 10 entries and relative ones $-9 \mathrm{ipm}$, the General Corpus of the Mongolian Language numbering a total of 1818 such patterns.

Keywords: Mongolian language, corpus linguistics, quantitative research methods in linguistics, analytical constructions, analytical forms

Acknowledgements: The reported study was funded by comprehensive fundamental research program of the Department of Historical and Philological Sciences of the RAS ('Eurasianist Heritage and Its Contemporary Narratives', subprogram 'General Corpus of Modern Mongolian: Creatinng Version No. 3'), and by RFBR (project numbers 18-012-00611 'Structural and Probabilistic Morphology of Mongolic Languages' and 19-512-44017 'Structural and Probabilistic Integral Model of Mongolic Languages').

For citation: Krylov S. A. Structural Diagrams of Mongolian Analytical Constructions in a Quantitative Aspect. Oriental Studies. 2019;(5): 974-1006. DOI: 10.22162/2619-0990-2019-45-5974-1006.
\end{abstract}

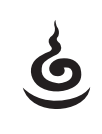

В настоящей работе ставится задача измерить употребительность аналитических форм (= «аналитических конструкций», далее - АК) монгольского языка. Одна из острых проблем такого исследования заключается в том, что границы самого инвентаря АК не вполне ясны ${ }^{1}$. Представляется, что это множество имеет диффузную природу, т. е. его границы расплывчаты. Тем не менее они поддаются исследованию достаточно точными методами, если эти

${ }^{1}$ В связи с этим предлагаемый 3. М. Шаляпиной подход к аналитическим формам, при котором они включаются в более широкое понятие «морфолого-синтаксических перифраз» [Шаляпина 2007: 121-123], как кажется, является эффективным также применительно к монгольским аналитическим конструкциям.

методы будут иметь характер, адекватный своему реальному объекту, т. е. вероятностную квантитативную природу. Для этого необходимо на некотором первичном этапе исследования условиться, какие именно объективно измеримые характеристики есть у АК.

Представляется, что эвристически наиболее эффективный подход к АК - так называемый «широкий» подход, представленный в так называемой теории «грамматикализации» [Meillet 1912] ${ }^{2}$, а также «грамматизации» (в отечественном языкознании), например, работами: [Виноградов 1947; Кацнельсон 1948; Жирмунский 1963;

\footnotetext{
${ }^{2}$ См. также работы Б. Хайне, Кр. Лемана, Дж. Байби (1980-х гг.), а в XXI в. - работы Н. Р. Сумбатовой, Т. А. Майсака и др. [Lehmann 1982].
} 
Гак 1965; Маслов 1975; Маслов 1978] и других авторов. Те оценки семантических и синтаксических особенностей АК, которые даются в этих работах, заслуживают внимания. Однако авторы указанных работ при выделении АК не прибегают к количественным (статистическим, квантитативным) приёмам. И поэтому встаёт вопрос о применимости дистрибутивно-вероятностного подхода ${ }^{3}$ к самой процедуре выделения АК.

Целью настоящей работы будет первичная квантитативная систематизация материала монгольского языка на материале специально разработанного автором Генерального корпуса современного монгольского языка (ГКМЯ-1а), представленного в ряде предшествующих публикаций автора: [Крылов 2014; Крылов 2012а; Крылов 2012б; Крылов 2013; Крылов 2014; Крылов 2016; Крылов 2017а; Крылов 2017б; Крылов 2017в; Крылов 2018а; Крылов 2108б; Крылов 2018в].

Изложение данных будет более наглядным, если мы представим его в форме таблицы. В эту таблицу включены не все АК монгольского языка, а лишь наиболее употребительные. Пороговое значение для включения в список составляет 10 вхождений в корпус ГКМЯ-1а, или 9 ipm. Таких словоформ оказалось 1818.

Аналитическая грамматема (аналитическая грамматическая форма) представлена как сочетание определённой синтетической грамматемы с определённой аналитической структурной схемой.

В первом столбце (I) (полужирным прямым шрифтом) приводится та синтетическая грамматема (грамматическая форма), к которой принадлежит синтетическая словоформа, функционирующая как знаменательный компонент данной АК.

Во втором столбце (II) приведена суммарная частотность этой синтетической грамматемы по корпусу ГКМЯ-1а.

В третьем столбце (III) приведена относительная частотность (в ірm) этой синтетической грамматемы по корпусу ГКМЯ-1а.

В четвёртом столбце (IV) приведён частотный ранг данной синтетической грамматемы по корпусу ГКМЯ-1а.

3 Принципы квантитативной систематизации нашего материала восходят к идеям А. Я. Шайкевича. О дистрибутивно-статистическом анализе языка см. подробнее в работах: [Шайкевич, Андрющенко, Ребецкая 2013; Шайкевич, Андрющенко, Ребецкая 2016].
В пятом столбце (V) (светлым курсивом) приведены сами аналитические формы в квазиорфографической записи. Следует обратить внимание на то, что порядок компонентов во всех аналитических формах жёстко фиксирован; во всяком случае, на всём диагностическом множестве из 1818 словоформ порядок компонентов не был подвержен варьированию.

В шестом столбце (VI) (полужирным курсивом) приведена та аналитическая структурная схема, к которой относится данная аналитическая форма (всего в данной таблице использовано 285 аналитических структурных моделей). Структурная схема состоит из постоянного и переменного компонентов (константа+переменная). Постоянный компонент представляет собой некоторую служебную (или полуслужебную) словоформу (или, в некоторых особых случаях, комплекс из нескольких служебных словоформ). Переменный компонент представляет собой условный обобщённый символ знаменательной синтетической словоформы (в качестве такого условного символа выбран значок $Z$ ). Переменный компонент (знаменательная синтетическая словоформа), в свою очередь, по своей структуре бинарен. Он представляет собой сочетание служебного (грамматического) компонента (т. е. некоторой синтетической условной грамматемы) с некоторой условной лексемой. Синтетическая условная грамматема в таблице представлена её именем в первом столбце (I), а условная лексема (ради компактности) не приводится вообще; однако читатель большей частью может легко догадаться, какая лексема имеется в виду, так как в виде одной из её синтетических словоформ данная лексема входит в качестве компонента в аналитические формы, задаваемые в пятом столбце (V).

В седьмом столбце (VII) приведена суммарная употребительность данной аналитической грамматемы по корпусу ГКМЯ-1а.

В восьмом столбце (VIII) приведена суммарная относительная частотность (в ipm) данной аналитической грамматемы по корпусу ГКМЯ-1а. Пороговое значение для включения в таблицу составляет $9 \mathrm{ipm}$.

В девятом столбце (IX) приведён частотный ранг данной аналитической грамматемы в корпусе ГКМЯ-1а.

В первых четырёх столбцах повтор имени синтетической грамматемы (в столбце I) и её количественных характеристик (в столбцах II, III и IV) для наглядности заменяется символом тильды $(\sim)$. 
Таблица структурных классов монгольских аналитических конструкций

\begin{tabular}{|c|c|c|c|c|c|c|c|c|}
\hline $\mathrm{I}$ & II & III & IV & $\mathrm{V}$ & VI & VII & VIII & IX \\
\hline A.COM & 55 & 48 & 73 & гэрm $\mathrm{Hb}$ & $Z \mathrm{Hb}$ & 33 & 29 & 275 \\
\hline$\sim$ & $\sim$ & $\sim$ & $\sim$ & гэрт орж & Z оржс & 22 & 19 & 382 \\
\hline A.COM-NOM & 94 & 83 & 48 & гэж итгэлт & гэюс $Z$ & 54 & 48 & 158 \\
\hline$\sim$ & $\sim$ & $\sim$ & $\sim$ & гээд итгэлт & гээд $Z$ & 40 & 35 & 221 \\
\hline $\begin{array}{l}\text { A.COM-NOM \& } \\
\text { DAT }\end{array}$ & 47 & 42 & 84 & өвөрт нь; хацарт нь & $Z$ Hb & 35 & 31 & 258 \\
\hline$\sim$ & $\sim$ & $\sim$ & $\sim$ & энэ нутагт & энэ $Z$ & 12 & 11 & 663 \\
\hline A.COM-NOM & 94 & 83 & 48 & гэж итгэлт хэлээд & гэю⿻ $Z$ хэлээд & 10 & 9 & 801 \\
\hline A.COP & 12 & 11 & 172 & нөгөөх $\mathrm{Hb}$ & $Z \mathrm{Hb}$ & 12 & 11 & 664 \\
\hline ABL & 326 & 288 & 26 & түҮнээс биш & Z биш & 17 & 15 & 471 \\
\hline$\sim$ & $\sim$ & $\sim$ & $\sim$ & гэрээс гарч & $Z$ zapu & 19 & 17 & 432 \\
\hline$\sim$ & $\sim$ & $\sim$ & $\sim$ & хаанаас даа & $Z \partial a a$ & 15 & 13 & 523 \\
\hline$\sim$ & $\sim$ & $\sim$ & $\sim$ & $\begin{array}{l}\text { талаас нb; нүднээс нb; } \\
\text { гараас нb; амнаас нb; } \\
\text { бүрээс нь; сэтгэлээс нb }\end{array}$ & $Z \boldsymbol{H b}$ & 120 & 107 & 75 \\
\hline$\sim$ & $\sim$ & $\sim$ & $\sim$ & $\begin{array}{l}\text { ҮҮнээс } \\
\text { хойщ }\end{array}$ & $Z$ хойш & 54 & 48 & 159 \\
\hline$\sim$ & $\sim$ & $\sim$ & $\sim$ & $\begin{array}{l}\text { хэнээс ч; хаанаас } и ; \\
\text { юунаас ч }\end{array}$ & $Z u$ & 42 & 37 & 211 \\
\hline$\sim$ & $\sim$ & $\sim$ & $\sim$ & би чамаас & би $Z$ & 14 & 12 & 568 \\
\hline$\sim$ & $\sim$ & $\sim$ & $\sim$ & гэж өөрөөсөө & гэюс $Z$ & 13 & 11 & 606 \\
\hline$\sim$ & $\sim$ & $\sim$ & $\sim$ & нөгөө талаас & нөгөө $Z$ & 11 & 10 & 730 \\
\hline$\sim$ & $\sim$ & $\sim$ & $\sim$ & тэр изагаас хойш & тэр $Z$ хойш & 21 & 18 & 397 \\
\hline ABL-POSS.REFL & 28 & 25 & 109 & өөрөөс нь & $Z$ Hb & 28 & 25 & 316 \\
\hline ABL? & 53 & 47 & 74 & $\theta \theta д \theta \theta с н ь$ & $Z \mathrm{Hb}$ & 53 & 47 & 165 \\
\hline ABS-GEN-NOM & 148 & 130 & 40 & бид хоёрын & бид $Z$ & 57 & 50 & 145 \\
\hline$\sim$ & $\sim$ & $\sim$ & $\sim$ & тэр хоёрынн & mэр $Z$ & 30 & 26 & 298 \\
\hline$\sim$ & $\sim$ & $\sim$ & $\sim$ & энэ хоёрын & энэ $Z$ & 22 & 19 & 383 \\
\hline$\sim$ & $\sim$ & $\sim$ & $\sim$ & та хоёрын & $m a Z$ & 17 & 15 & 472 \\
\hline$\sim$ & $\sim$ & $\sim$ & $\sim$ & чи бид хоёрын & чи бид $Z$ & 12 & 11 & 665 \\
\hline$\sim$ & $\sim$ & $\sim$ & $\sim$ & хоёрьнн дунд & $Z$ дунд & 10 & 9 & 802 \\
\hline ABS-GEN/ACC & 15 & 13 & 150 & нэгий нь & $Z \mathrm{Hb}$ & 15 & 13 & 524 \\
\hline ABS-INSTR & $\sim$ & $\sim$ & 151 & нэг нэгээр нь & нэг $Z$ нb & 15 & 13 & 525 \\
\hline ABS-NOM \& ABL & 13 & 11 & 163 & бор гөрөөс & бор $Z$ & 13 & 11 & 607 \\
\hline ABS-NOM & 1663 & 1461 & 3 & $\begin{array}{l}\text { нэг нь; нүд нь; өглөө нь; } \\
\text { ам нь; санаа нь; ус нь; } \\
\text { Үг нь; амьсгаа нь; заяа } \\
\text { нь; мах нь; чимээ нь; } \\
\text { хаалга нь }\end{array}$ & $Z$ нb & 740 & 650 & 6 \\
\hline$\sim$ & $\sim$ & $\sim$ & $\sim$ & нэг л & $Z_{\pi}$ & 282 & 248 & 30 \\
\hline$\sim$ & $\sim$ & $\sim$ & $\sim$ & нэг удааа; анх удаа & Z yдаa & 151 & 132 & 58 \\
\hline$\sim$ & $\sim$ & $\sim$ & $\sim$ & нэг ч; үг ч & $Z \boldsymbol{u}$ & 93 & 82 & 91 \\
\hline$\sim$ & $\sim$ & $\sim$ & $\sim$ & нэг юм & $Z$ юм & 84 & 74 & 100 \\
\hline$\sim$ & $\sim$ & $\sim$ & $\sim$ & санаа алдан & $Z$ алдан & 55 & 48 & 155 \\
\hline$\sim$ & $\sim$ & $\sim$ & $\sim$ & $\begin{array}{l}\text { ус руу; ам руу; хаалга } \\
\text { pyy }\end{array}$ & $Z$ pyy & 45 & 40 & 199 \\
\hline$\sim$ & $\sim$ & $\sim$ & $\sim$ & ус шиг; нүд ииг & $Z$ шиг & 38 & 33 & 238 \\
\hline$\sim$ & $\sim$ & $\sim$ & $\sim$ & нэг бол & $Z$ бол & 33 & 29 & 276 \\
\hline$\sim$ & $\sim$ & $\sim$ & $\sim$ & чимээ гарч & $Z$ zapu & 24 & 21 & 354 \\
\hline$\sim$ & $\sim$ & $\sim$ & $\sim$ & Үг яриа & $Z$ яриа & 21 & 18 & 398 \\
\hline
\end{tabular}


Oriental Studies. 2019. Is. 5

\begin{tabular}{|c|c|c|c|c|c|c|c|c|}
\hline$\sim$ & $\sim$ & $\sim$ & $\sim$ & уг хэлж & $Z$ хэлюс & 20 & 18 & 421 \\
\hline$\sim$ & $\sim$ & $\sim$ & $\sim$ & Уг хэлэх & $Z$ хэлэх & 15 & 13 & 526 \\
\hline$\sim$ & $\sim$ & $\sim$ & $\sim$ & нэг ч үгүй & $Z$ ч үгуй & 15 & 13 & 527 \\
\hline$\sim$ & $\sim$ & $\sim$ & $\sim$ & нэг л биш & $Z$ л биш & 13 & 11 & 610 \\
\hline$\sim$ & $\sim$ & $\sim$ & $\sim$ & нэг дор & $Z$ дор & 12 & 11 & 667 \\
\hline$\sim$ & $\sim$ & $\sim$ & $\sim$ & нүд чинь & $Z$ чинь & 12 & 11 & 668 \\
\hline$\sim$ & $\sim$ & $\sim$ & $\sim$ & өрөө рүY & $Z_{p Y Y}$ & 10 & 9 & 803 \\
\hline $\begin{array}{l}\text { ABS-NOM \& CVB. } \\
\text { CNGR }\end{array}$ & 31 & 27 & 103 & гэж бадарч & гэж $Z$ & 18 & 16 & 454 \\
\hline$\sim$ & $\sim$ & $\sim$ & $\sim$ & гээд бадарч & гээд $Z$ & 13 & 11 & 608 \\
\hline ABS-NOM \& DAT & 12 & 11 & 173 & зҮҮд шиг & $Z$ шиг & 12 & 11 & 666 \\
\hline ABS-NOM \& NOM & 110 & 97 & 44 & мод шиг; уул шиг & $Z$ шиг & 47 & 42 & 186 \\
\hline$\sim$ & $\sim$ & $\sim$ & $\sim$ & уул нь & $Z$ Hb & 36 & 32 & 250 \\
\hline$\sim$ & $\sim$ & $\sim$ & $\sim$ & уул өөд & $Z \boldsymbol{\theta \theta \partial}$ & 14 & 12 & 569 \\
\hline$\sim$ & $\sim$ & $\sim$ & $\sim$ & энэ уул & энэ $Z$ & 13 & 11 & 609 \\
\hline \begin{tabular}{ll|} 
ABS-NOM & $\&$ \\
POSS.REFL & \\
\end{tabular} & 14 & 12 & 155 & шороо нь & $Z \mathrm{Hb}$ & 14 & 12 & 570 \\
\hline ABS-NOM & 1663 & 1461 & 3 & $\theta ө р Y^{2}$ & өөр $Z$ & 12 & 11 & 669 \\
\hline$\sim$ & $\sim$ & $\sim$ & $\sim$ & бид гурав & бид $Z$ & 15 & 13 & 528 \\
\hline$\sim$ & $\sim$ & $\sim$ & $\sim$ & гэсэн Х $^{2}$ & гэсэн $Z$ & 123 & 108 & 72 \\
\hline$\sim$ & $\sim$ & $\sim$ & $\sim$ & $\begin{array}{l}\text { гэж ам; гэж санаа; гэж } \\
Y^{2}\end{array}$ & гэю⿻ $Z$ & 58 & 52 & 142 \\
\hline$\sim$ & $\sim$ & $\sim$ & $\sim$ & гэдэг Yट & гэдэг $Z$ & 42 & 37 & 212 \\
\hline$\sim$ & $\sim$ & $\sim$ & $\sim$ & гэсэн ҮС вэ & гэсэн $Z$ вэ & 32 & 28 & 284 \\
\hline$\sim$ & $\sim$ & $\sim$ & $\sim$ & гээд санаа & гээд $Z$ & 15 & 13 & 529 \\
\hline$\sim$ & $\sim$ & $\sim$ & $\sim$ & ийм $Y^{2}$ & иймn $Z$ & 19 & 17 & 433 \\
\hline$\sim$ & $\sim$ & $\sim$ & $\sim$ & нэг өглөө & нэг $Z$ & 20 & 18 & 422 \\
\hline$\sim$ & $\sim$ & $\sim$ & $\sim$ & нэгэн өглөө & нэгэн $Z$ & 10 & 9 & 804 \\
\hline$\sim$ & $\sim$ & $\sim$ & $\sim$ & тэр гурав; тэр өглөө & mэр $Z$ & 25 & 22 & 337 \\
\hline$\sim$ & $\sim$ & $\sim$ & $\sim$ & хэдэн $Y^{2}$ & хэдэн $Z$ & 30 & 26 & 299 \\
\hline$\sim$ & $\sim$ & $\sim$ & $\sim$ & энэ үг; энэ гурав & энэ $Z$ & 48 & 42 & 182 \\
\hline $\mathrm{ACC} \& \mathrm{ACC}$ & 74 & 66 & 61 & юмblг $\mathrm{Hb}$ & $Z$ Hb & 12 & 11 & 670 \\
\hline$\sim$ & $\sim$ & $\sim$ & $\sim$ & юмыг яаж мэдэх вэ & \begin{tabular}{|l|} 
яаж мэдэх \\
вэ
\end{tabular} & 12 & 11 & 671 \\
\hline$\sim$ & $\sim$ & $\sim$ & $\sim$ & ма нарыг & $\operatorname{ma} Z$ & 50 & 44 & 179 \\
\hline $\mathbf{A C C}$ & 978 & 862 & 7 & зугийг барин & $Z$ барин & 10 & 9 & 805 \\
\hline$\sim$ & $\sim$ & $\sim$ & $\sim$ & зурхийг минь & Zммин & 17 & 15 & 473 \\
\hline$\sim$ & $\sim$ & $\sim$ & $\sim$ & учрыц мэдэж & $Z$ м.эдэю & 10 & 9 & 806 \\
\hline$\sim$ & $\sim$ & $\sim$ & $\sim$ & 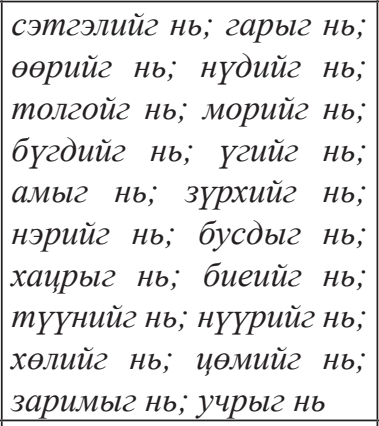 & $Z$ Hb & 381 & 335 & 21 \\
\hline$\sim$ & $\sim$ & $\sim$ & $\sim$ & учрыг олж & $Z$ олюс & 12 & 11 & 672 \\
\hline$\sim$ & $\sim$ & $\sim$ & $\sim$ & Үнэнийг хэлэхэд & $Z$ хэлэхэд & 24 & 21 & 355 \\
\hline$\sim$ & $\sim$ & $\sim$ & $\sim$ & хэнийг ч; юуг ч & $Z \boldsymbol{u}$ & 30 & 26 & 300 \\
\hline$\sim$ & $\sim$ & $\sim$ & $\sim$ & шарильгг эргэн & $Z$ эргэн & 12 & 11 & 673 \\
\hline$\sim$ & $\sim$ & $\sim$ & $\sim$ & би танылг & би $Z$ & 28 & 25 & 317 \\
\hline
\end{tabular}




\begin{tabular}{|c|c|c|c|c|c|c|c|c|}
\hline$\sim$ & $\sim$ & $\sim$ & $\sim$ & бид хоёрьг & бид $Z$ & 39 & 34 & 232 \\
\hline$\sim$ & $\sim$ & $\sim$ & $\sim$ & гэдэг үгийг & гэдэг $Z$ & 35 & 31 & 259 \\
\hline$\sim$ & $\sim$ & $\sim$ & $\sim$ & гэсэн үгийг & гэсэн $Z$ & 11 & 10 & 731 \\
\hline$\sim$ & $\sim$ & $\sim$ & $\sim$ & $\begin{array}{l}\text { миний үгийг; миний } \\
\text { сэтгэлийг }\end{array}$ & миний Z & 24 & 21 & 356 \\
\hline$\sim$ & $\sim$ & $\sim$ & $\sim$ & $\begin{array}{l}\text { нэг бүрийг; нэг хүнийг; } \\
\text { нэг зүйлий }\end{array}$ & нэг $Z$ & 43 & 38 & 209 \\
\hline$\sim$ & $\sim$ & $\sim$ & $\sim$ & түҮний сэтгэлийг & 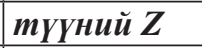 & 17 & 15 & 474 \\
\hline$\sim$ & $\sim$ & $\sim$ & $\sim$ & ma хоёрыг & $\operatorname{ma} Z$ & 13 & 11 & 611 \\
\hline$\sim$ & $\sim$ & $\sim$ & $\sim$ & $\begin{array}{l}\text { тэр хоёрыс; тэр хүнийг; } \\
\text { мэр үгийг; тэр бүрийг }\end{array}$ & mэр $Z$ & 88 & 78 & 97 \\
\hline$\sim$ & $\sim$ & $\sim$ & $\sim$ & $\begin{array}{l}\text { энэ үгийг; энэ тэрийг; } \\
\text { энэ хүнийг; энэ дууг; энэ } \\
\text { хоёрысг }\end{array}$ & энэ $Z$ & 184 & 162 & 48 \\
\hline CAR-NOM & 228 & 201 & 30 & байлгүй дээ & $Z$ дээ & 42 & 37 & 213 \\
\hline$\sim$ & $\sim$ & $\sim$ & $\sim$ & аргагүйл & $Z \pi$ & 40 & 35 & 222 \\
\hline$\sim$ & $\sim$ & $\sim$ & $\sim$ & байлгүй яахав & $Z$ яахав & 21 & 18 & 399 \\
\hline$\sim$ & $\sim$ & $\sim$ & $\sim$ & дуугүй болов & $Z$ болов & 20 & 18 & 423 \\
\hline$\sim$ & $\sim$ & $\sim$ & $\sim$ & дуугүй байснаа & Z байснаа & 18 & 16 & 455 \\
\hline$\sim$ & $\sim$ & $\sim$ & $\sim$ & аргагүй болж & $Z$ болюс & 10 & 9 & 807 \\
\hline$\sim$ & $\sim$ & $\sim$ & $\sim$ & аргагуй шүY дээ & $Z$ шиY дээ & 10 & 9 & 808 \\
\hline$\sim$ & $\sim$ & $\sim$ & $\sim$ & аргагүй юм & $Z$ юм & 10 & 9 & 809 \\
\hline$\sim$ & $\sim$ & $\sim$ & $\sim$ & байлгүй яах вэ & $Z$ яах вэ & 10 & 9 & 810 \\
\hline$\sim$ & $\sim$ & $\sim$ & $\sim$ & өөр аргагүй; өөр юмгүй & $\operatorname{\theta \theta p} Z$ & 34 & 30 & 265 \\
\hline$\sim$ & $\sim$ & $\sim$ & $\sim$ & өөр аргагуй болов & өөр $Z$ болов & 13 & 11 & 612 \\
\hline COM-NOM & 283 & 248 & 27 & ёстойл & $Z_{\boldsymbol{I}}$ & 103 & 91 & 83 \\
\hline$\sim$ & $\sim$ & $\sim$ & $\sim$ & юутай ч; хэнтэй ч & $Z u$ & 46 & 40 & 192 \\
\hline$\sim$ & $\sim$ & $\sim$ & $\sim$ & хэрэгтэй юм; ёстой юм & $Z$ юм & 34 & 30 & 266 \\
\hline$\sim$ & $\sim$ & $\sim$ & $\sim$ & хэрэгтэй байлаа & $Z$ байлаа & 13 & 11 & 613 \\
\hline$\sim$ & $\sim$ & $\sim$ & $\sim$ & хэрэгтэй болов & $Z$ болов & 13 & 11 & 614 \\
\hline$\sim$ & $\sim$ & $\sim$ & $\sim$ & өөртэй нь & $Z$ Hb & 13 & 11 & 615 \\
\hline$\sim$ & $\sim$ & $\sim$ & $\sim$ & хэрэгтэй байна & $Z$ байна & 11 & 10 & 732 \\
\hline$\sim$ & $\sim$ & $\sim$ & $\sim$ & бор изарайтай & бор $Z$ & 13 & 11 & 616 \\
\hline$\sim$ & $\sim$ & $\sim$ & $\sim$ & гэсэн бололтой & гэсэн $Z$ & 15 & 13 & 530 \\
\hline$\sim$ & $\sim$ & $\sim$ & $\sim$ & гэдэг нэртэй & гэдэг $Z$ & 10 & 9 & 811 \\
\hline$\sim$ & $\sim$ & $\sim$ & $\sim$ & хэдэн морьтой & Хэдэн $Z$ & 12 & 11 & 674 \\
\hline $\begin{array}{l}\text { COP.IRREAL } \\
\text { \& PC.US-COP. } \\
\text { IRREAL } \\
\end{array}$ & 23 & 20 & 125 & болдогсон бол & $Z$ бол & 23 & 20 & 369 \\
\hline $\begin{array}{l}\text { COP.IRREAL \& } \\
\text { REL-NOM }\end{array}$ & 13 & 11 & 164 & юмсан уу & $Z y y$ & 13 & 11 & 617 \\
\hline CVB.ANT & 787 & 695 & 12 & $\begin{array}{l}\text { тэгээд л; гээд л; ингээд } \\
л\end{array}$ & $Z_{\pi}$ & 200 & 177 & 41 \\
\hline$\sim$ & $\sim$ & $\sim$ & $\sim$ & пэгээд ч & $Z \boldsymbol{u}$ & 76 & 67 & 113 \\
\hline$\sim$ & $\sim$ & $\sim$ & $\sim$ & Хүрээд ирлээ & $Z$ ирлээ & 17 & 15 & 475 \\
\hline$\sim$ & $\sim$ & $\sim$ & $\sim$ & ҮҮнийг хараад & ҮҮнийс $Z$ & 10 & 9 & 812 \\
\hline$\sim$ & $\sim$ & $\sim$ & $\sim$ & бас тэгээд & бас $Z$ & 69 & 61 & 123 \\
\hline$\sim$ & $\sim$ & $\sim$ & $\sim$ & 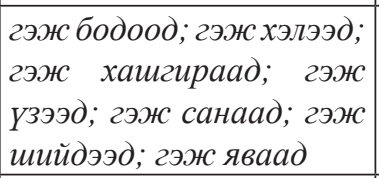 & 2э\%с $Z$ & 374 & 329 & 23 \\
\hline$\sim$ & $\sim$ & $\sim$ & $\sim$ & гэж ирээд л & гэж⿻ $Z$ л & 11 & 10 & 733 \\
\hline$\sim$ & $\sim$ & $\sim$ & $\sim$ & та тэгээд & $m a Z$ & 10 & 9 & 813 \\
\hline
\end{tabular}


Oriental Studies. 2019. Is. 5

\begin{tabular}{|c|c|c|c|c|c|c|c|c|}
\hline$\sim$ & $\sim$ & $\sim$ & $\sim$ & чи тэгээд & чи $Z$ & 20 & 18 & 424 \\
\hline CVB.CNGR & 1714 & 1505 & 2 & $\begin{array}{l}\text { гэж байна; харагдаж } \\
\text { байна; асууж байна; } \\
\text { санаж байна; зогсож } \\
\text { байна; итгэж байна; } \\
\text { хүлээж байна; хүсэж } \\
\text { байна }\end{array}$ & Z байна & 233 & 206 & 32 \\
\hline$\sim$ & $\sim$ & $\sim$ & $\sim$ & гэж $Y Y$ & $Z_{Y Y}$ & 216 & 190 & 37 \\
\hline$\sim$ & $\sim$ & $\sim$ & $\sim$ & $\begin{array}{l}\text { гээ байгаа; зогсож } \\
\text { байгаа; идэж байгаа; } \\
\text { унтаж байгаа; хүлээж } \\
\text { байгаа; харагдаж } \\
\text { байгаа; урсаж байгаа; } \\
\text { тоглож байгаа }\end{array}$ & Z байгаа & 197 & 173 & 42 \\
\hline$\sim$ & $\sim$ & $\sim$ & $\sim$ & $\begin{array}{lr}\text { зогсож } & \text { байлаа; } \\
\text { санагдаж } & \text { байлаа; } \\
\text { хүлээж байлаа; унтаж } \\
\text { байлаа; чичирч байлаа }\end{array}$ & Z байлаа & 82 & 72 & 103 \\
\hline$\sim$ & $\sim$ & $\sim$ & $\sim$ & 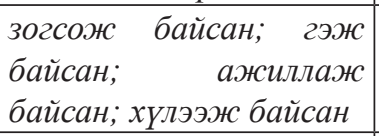 & Z байсан & 77 & 67 & 109 \\
\hline$\sim$ & $\sim$ & $\sim$ & $\sim$ & $\begin{array}{l}\text { зогсож байв; санагдаж } \\
\text { байв; ажиллаж байв }\end{array}$ & $Z$ байв & 61 & 54 & 136 \\
\hline$\sim$ & $\sim$ & $\sim$ & $\sim$ & гэж л; ингэж л; тэгж л & $Z_{\pi}$ & 52 & 46 & 170 \\
\hline$\sim$ & $\sim$ & $\sim$ & $\sim$ & гэж дээ & $Z$ дээ & 47 & 41 & 187 \\
\hline$\sim$ & $\sim$ & $\sim$ & $\sim$ & $\begin{array}{l}\text { буиажс ирээд; гүйж } \\
\text { ирээд; давхиж ирээд }\end{array}$ & $Z$ ирээд & 46 & 40 & 193 \\
\hline$\sim$ & $\sim$ & $\sim$ & $\sim$ & $\begin{array}{l}\text { тэгж байтал; гэж } \\
\text { байтал }\end{array}$ & Z байтал & 45 & 39 & 200 \\
\hline$\sim$ & $\sim$ & $\sim$ & $\sim$ & $\begin{array}{l}\text { санаж байна уу; гэж } \\
\text { байна уу }\end{array}$ & Z байна уу & 41 & 36 & 218 \\
\hline$\sim$ & $\sim$ & $\sim$ & $\sim$ & $\begin{array}{lr}\text { ширтэж } & \text { байснаа; } \\
\text { зогсож } & \text { байснаа; } \\
\text { ажиглаж байснаа }\end{array}$ & Z байснаа & 36 & 32 & 251 \\
\hline$\sim$ & $\sim$ & $\sim$ & $\sim$ & $\begin{array}{l}\text { татаж аваад; шүүрч } \\
\text { аваад }\end{array}$ & $Z$ abaad & 27 & 24 & 324 \\
\hline$\sim$ & $\sim$ & $\sim$ & $\sim$ & гэж байгаа юм шиг & $\begin{array}{l}Z \text { байгаа юм } \\
\text { ииг }\end{array}$ & 25 & 22 & 338 \\
\hline$\sim$ & $\sim$ & $\sim$ & $\sim$ & гэж байгааг & Z байгааг & 23 & 20 & 370 \\
\hline$\sim$ & $\sim$ & $\sim$ & $\sim$ & $\begin{array}{l}\text { тулгаж байгаад; гэж } \\
\text { байгаад } \\
\end{array}$ & Z байгаад & 21 & 19 & 400 \\
\hline$\sim$ & $\sim$ & $\sim$ & $\sim$ & гэж байдаг & $Z$ байдаг & 21 & 18 & 401 \\
\hline$\sim$ & $\sim$ & $\sim$ & $\sim$ & гэж байхад & Z байхад & 17 & 15 & 476 \\
\hline$\sim$ & $\sim$ & $\sim$ & $\sim$ & гэж билээ & Z билээ & 17 & 15 & 477 \\
\hline$\sim$ & $\sim$ & $\sim$ & $\sim$ & гэж бий & $Z$ бий & 16 & 14 & 502 \\
\hline$\sim$ & $\sim$ & $\sim$ & $\sim$ & гэж байгаа нь & $Z$ байгаа нь & 15 & 13 & 531 \\
\hline$\sim$ & $\sim$ & $\sim$ & $\sim$ & гэж байхгуй & $Z$ байхгуй & 15 & 13 & 532 \\
\hline$\sim$ & $\sim$ & $\sim$ & $\sim$ & худалдаж авсан & $Z$ авсан & 14 & 12 & 571 \\
\hline$\sim$ & $\sim$ & $\sim$ & $\sim$ & гэж байгаа юм & Z байгаа юм & 14 & 12 & 572 \\
\hline$\sim$ & $\sim$ & $\sim$ & $\sim$ & гэж байх уy & $Z$ байх yу & 14 & 12 & 573 \\
\hline$\sim$ & $\sim$ & $\sim$ & $\sim$ & авчирч өгсөн & $Z$ өгсөн & 13 & 11 & 618 \\
\hline$\sim$ & $\sim$ & $\sim$ & $\sim$ & гүйж очоод & Z очоод & 13 & 11 & 619 \\
\hline$\sim$ & $\sim$ & $\sim$ & $\sim$ & ингэж явсаар & $Z$ явсаар & 13 & 11 & 620 \\
\hline$\sim$ & $\sim$ & $\sim$ & $\sim$ & гэж $Y Y$ дээ & $Z_{Y Y}$ дээ & 12 & 11 & 675 \\
\hline
\end{tabular}




\begin{tabular}{|c|c|c|c|c|c|c|c|c|}
\hline$\sim$ & $\sim$ & $\sim$ & $\sim$ & гэж байж & $Z$ байжс & 12 & 11 & 676 \\
\hline$\sim$ & $\sim$ & $\sim$ & $\sim$ & гэж ихл & $Z$ ихл & 12 & 11 & 677 \\
\hline$\sim$ & $\sim$ & $\sim$ & $\sim$ & буцзаж ирлээ & $Z$ ирлээ & 11 & 10 & 734 \\
\hline$\sim$ & $\sim$ & $\sim$ & $\sim$ & унаж яваа & $Z$ яваа & 11 & 10 & 735 \\
\hline$\sim$ & $\sim$ & $\sim$ & $\sim$ & зааж өгнө & $Z$ өгия & 10 & 9 & 814 \\
\hline$\sim$ & $\sim$ & $\sim$ & $\sim$ & гэж байгаа бол & Z байгаа бол & 10 & 9 & 815 \\
\hline$\sim$ & $\sim$ & $\sim$ & $\sim$ & гэж гэнэ & $Z$ гэнэ & 10 & 9 & 816 \\
\hline$\sim$ & $\sim$ & $\sim$ & $\sim$ & би мэдэж байна & би $Z$ байна & 13 & 11 & 621 \\
\hline$\sim$ & $\sim$ & $\sim$ & $\sim$ & гэж бодож; гэж хэлж & гэю⿻ $Z$ & 77 & 67 & 110 \\
\hline$\sim$ & $\sim$ & $\sim$ & $\sim$ & гэж бодож байна & гэж⿻ $Z$ байна & 39 & 34 & 233 \\
\hline$\sim$ & $\sim$ & $\sim$ & $\sim$ & гэж бодож байлаа & \begin{tabular}{ll|} 
гэж⿻ & $Z$ \\
байлаа & \\
\end{tabular} & 14 & 12 & 574 \\
\hline$\sim$ & $\sim$ & $\sim$ & $\sim$ & гэж бодож байна уу & $\begin{array}{l}\text { гэжс Z байна } \\
y y\end{array}$ & 14 & 12 & 575 \\
\hline$\sim$ & $\sim$ & $\sim$ & $\sim$ & гэж бодож байсан & \begin{tabular}{|l|} 
гэж⿻ \\
байсан
\end{tabular} & 13 & 11 & 622 \\
\hline$\sim$ & $\sim$ & $\sim$ & $\sim$ & гэж бодож явлаа & гэж $Z$ явлаа & 13 & 11 & 623 \\
\hline$\sim$ & $\sim$ & $\sim$ & $\sim$ & гээд гарч & гээд $Z$ & 12 & 11 & 678 \\
\hline$\sim$ & $\sim$ & $\sim$ & $\sim$ & гэж бодож байв & гээ⿻ $Z$ байв & 10 & 9 & 817 \\
\hline$\sim$ & $\sim$ & $\sim$ & $\sim$ & энд ирж & энд $Z$ & 10 & 9 & 818 \\
\hline CVB.CONC & 13 & 11 & 165 & гэж бодовч & гэभ $Z$ & 13 & 11 & 624 \\
\hline CVB.COND1 & 41 & 37 & 90 & гэж асуувал & гэю⿻ $Z$ & 17 & 15 & 478 \\
\hline$\sim$ & $\sim$ & $\sim$ & $\sim$ & заавал ирнэ & $Z$ ирнэ & 12 & 11 & 679 \\
\hline$\sim$ & $\sim$ & $\sim$ & $\sim$ & пэгвэл ч & $Z \boldsymbol{y}$ & 12 & 11 & 680 \\
\hline CVB.MOD & 273 & 239 & 28 & $\begin{array}{l}\text { шүҮрэн авч; татан авч; } \\
\text { Хүлээн авч; тэврэн авч; } \\
\text { угтан авч; таслан авч }\end{array}$ & Z abu & 150 & 131 & 60 \\
\hline$\sim$ & $\sim$ & $\sim$ & $\sim$ & $\begin{array}{l}\text { хэмээн бодож; } \\
\text { эргэичүлэн бодож }\end{array}$ & Z бодож & 36 & 32 & 252 \\
\hline$\sim$ & $\sim$ & $\sim$ & $\sim$ & $\begin{array}{l}\text { давхин ирж; хүрэлиэн } \\
\text { ирж }\end{array}$ & Z иржс & 24 & 21 & 357 \\
\hline$\sim$ & $\sim$ & $\sim$ & $\sim$ & байн байн & $Z$ байн & 21 & 18 & 402 \\
\hline$\sim$ & $\sim$ & $\sim$ & $\sim$ & зүлгэн дээр & $Z$ дээр & 18 & 16 & 456 \\
\hline$\sim$ & $\sim$ & $\sim$ & $\sim$ & сөхрөн сууж & Z сууж & 13 & 11 & 626 \\
\hline$\sim$ & $\sim$ & $\sim$ & $\sim$ & завилан суугаад & Z суугаad & 11 & 10 & 736 \\
\hline $\begin{array}{l}\text { CVB.MOD \& REL- } \\
\text { NOM }\end{array}$ & 13 & 11 & 166 & чи бидэн & чи $Z$ & 13 & 11 & 625 \\
\hline CVB.MOD & 273 & 239 & 28 & 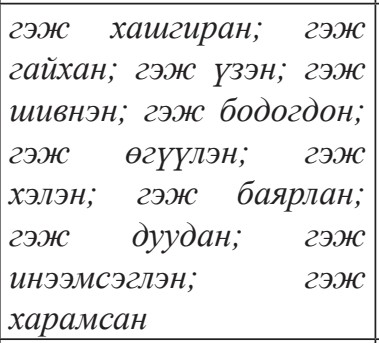 & гэж⿻ Z & 186 & 164 & 46 \\
\hline$\sim$ & $\sim$ & $\sim$ & $\sim$ & тас анин & $\operatorname{mac} Z$ & 11 & 10 & 737 \\
\hline CVB.PERSEV & 18 & 16 & 140 & гэж бодсоор & гэю $Z$ & 18 & 16 & 457 \\
\hline CVB.TERM & 80 & 71 & 56 & болтол нь & $Z$ нb & 17 & 15 & 479 \\
\hline$\sim$ & $\sim$ & $\sim$ & $\sim$ & тэгттэл ч & $Z u$ & 13 & 11 & 627 \\
\hline$\sim$ & $\sim$ & $\sim$ & $\sim$ & гэтэл энэ нь & $Z$ энэ нь & 10 & 9 & 819 \\
\hline$\sim$ & $\sim$ & $\sim$ & $\sim$ & \begin{tabular}{|l|l|} 
гэж & бодтол; $;$ гэжтэл \\
хэлтэл
\end{tabular} & гэюс $Z$ & 30 & 27 & 301 \\
\hline$\sim$ & $\sim$ & $\sim$ & $\sim$ & тас хийтэл & $\operatorname{mac} Z$ & 10 & 9 & 820 \\
\hline DAT & 797 & 704 & 11 & энд байгаа & $Z$ байгаа & 11 & 10 & 740 \\
\hline
\end{tabular}


Oriental Studies. 2019. Is. 5

\begin{tabular}{|c|c|c|c|c|c|c|c|c|}
\hline$\sim$ & $\sim$ & $\sim$ & $\sim$ & $\begin{array}{l}\text { зүрхэнд минь; сэтгэлд } \\
\text { минь }\end{array}$ & $Z$ минь & 22 & 20 & 384 \\
\hline$\sim$ & $\sim$ & $\sim$ & $\sim$ & 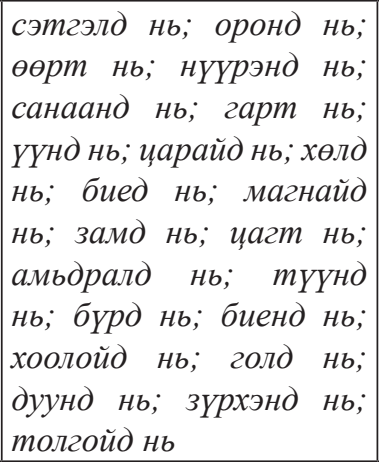 & $Z$ нь & 554 & 489 & 10 \\
\hline$\sim$ & $\sim$ & $\sim$ & $\sim$ & $\begin{array}{l}\text { усанд орж; үгэнд орж; } \\
\text { өрөөнд орж }\end{array}$ & Z оржс & 37 & 33 & 245 \\
\hline$\sim$ & $\sim$ & $\sim$ & $\sim$ & над руy & $Z$ pyy & 42 & 37 & 214 \\
\hline$\sim$ & $\sim$ & $\sim$ & $\sim$ & хэнд ч; юунд ч & $Z y$ & 72 & 63 & 116 \\
\hline$\sim$ & $\sim$ & $\sim$ & $\sim$ & энд чинь & $Z$ чинь & 11 & 10 & 741 \\
\hline$\sim$ & $\sim$ & $\sim$ & $\sim$ & над ииг & $Z$ шиг & 48 & 42 & 183 \\
\hline DAT \& CVB.ANT & 10 & 9 & 206 & гэж оролдоод & гэю⿻ $Z$ & 10 & 9 & 821 \\
\hline DAT & 797 & 704 & 11 & би танд & би $Z$ & 25 & 22 & 339 \\
\hline$\sim$ & $\sim$ & $\sim$ & $\sim$ & бид хоёрт & бид $Z$ & 24 & 21 & 358 \\
\hline$\sim$ & $\sim$ & $\sim$ & $\sim$ & ийм үед & ийм $Z$ & 21 & 18 & 403 \\
\hline$\sim$ & $\sim$ & $\sim$ & $\sim$ & миний сэтгэлд & миний $Z$ & 21 & 18 & 404 \\
\hline$\sim$ & $\sim$ & $\sim$ & $\sim$ & нөгөө талд & нөгөө $Z$ & 17 & 15 & 480 \\
\hline$\sim$ & $\sim$ & $\sim$ & $\sim$ & нэг хүнд & нэг $Z$ & 12 & 11 & 682 \\
\hline$\sim$ & $\sim$ & $\sim$ & $\sim$ & нэгэн и̧агт & нэгэн $Z$ & 45 & 40 & 201 \\
\hline$\sim$ & $\sim$ & $\sim$ & $\sim$ & түҮний оронд & 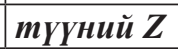 & 10 & 9 & 825 \\
\hline$\sim$ & $\sim$ & $\sim$ & $\sim$ & та бүхэнд & $m a Z$ & 11 & 10 & 742 \\
\hline$\sim$ & $\sim$ & $\sim$ & $\sim$ & $\begin{array}{l}\text { тэр изагт; тэр үед; тэр } \\
\text { хүнд }\end{array}$ & mэр $Z$ & 124 & 109 & 71 \\
\hline$\sim$ & $\sim$ & $\sim$ & $\sim$ & хэн бүхэнд & хэн $Z$ & 10 & 9 & 826 \\
\hline$\sim$ & $\sim$ & $\sim$ & $\sim$ & чи юунд & чи $Z$ & 15 & 13 & 533 \\
\hline$\sim$ & $\sim$ & $\sim$ & $\sim$ & энд тэнд & энд $Z$ & 79 & 70 & 108 \\
\hline$\sim$ & $\sim$ & $\sim$ & $\sim$ & энд тэнд нь & энд $Z$ нь & 10 & 9 & 827 \\
\hline$\sim$ & $\sim$ & $\sim$ & $\sim$ & $\begin{array}{ll}\text { энэ } & \text { үед; энэ дэлхийд; } \\
\text { энэ } & \text { Угэнд; энэ удаад; } \\
\text { энэ } & \text { хүнд; энэ хорвоод; } \\
\text { энэ бүхэнд }\end{array}$ & энэ $Z$ & 225 & 198 & 35 \\
\hline DAT-ABL & 12 & 11 & 174 & энд тэндээс & энд $Z$ & 12 & 11 & 681 \\
\hline DAT-CAR-NOM & 32 & 28 & 101 & энд тэндгүй & энд $Z$ & 32 & 28 & 285 \\
\hline DAT-POSS.REFL & 151 & 134 & 39 & ердөөл & $Z_{\pi}$ & 40 & 35 & 223 \\
\hline$\sim$ & $\sim$ & $\sim$ & $\sim$ & гэж өөртөө & гэю⿻ $Z$ & 27 & 24 & 325 \\
\hline$\sim$ & $\sim$ & $\sim$ & $\sim$ & ицээжинд нь & $Z \mu \mathrm{b}$ & 18 & 16 & 458 \\
\hline$\sim$ & $\sim$ & $\sim$ & $\sim$ & гэртээ ирээд & $Z$ ирээд & 14 & 12 & 576 \\
\hline$\sim$ & $\sim$ & $\sim$ & $\sim$ & гартаа барьсан & Z барьсан & 11 & 10 & 738 \\
\hline$\sim$ & $\sim$ & $\sim$ & $\sim$ & гэртээ орж & Z орж⿻ & 11 & 10 & 739 \\
\hline$\sim$ & $\sim$ & $\sim$ & $\sim$ & гэртээ ирж & $Z$ ирюс & 10 & 9 & 822 \\
\hline$\sim$ & $\sim$ & $\sim$ & $\sim$ & ажилдаа явсан & Z явсан & 10 & 9 & 823 \\
\hline$\sim$ & $\sim$ & $\sim$ & $\sim$ & нэг хэсэгтээ & нэг $Z$ & 10 & 9 & 824 \\
\hline ESS2-ABL & 17 & 15 & 143 & дотроос нь & $Z \boldsymbol{H b}$ & 17 & 15 & 481 \\
\hline GEN-ACC & 65 & 57 & 66 & толгойгий нь; хэдий нь & $Z \boldsymbol{H b}$ & 26 & 23 & 332 \\
\hline$\sim$ & $\sim$ & $\sim$ & $\sim$ & хэдий ч & $Z \boldsymbol{u}$ & 18 & 16 & 459 \\
\hline$\sim$ & $\sim$ & $\sim$ & $\sim$ & аль хэдий нь & аль $Z$ нь & 21 & 18 & 405 \\
\hline
\end{tabular}




\begin{tabular}{|c|c|c|c|c|c|c|c|c|}
\hline GEN-NOM & 846 & 747 & 9 & $\begin{array}{lrr}\text { жилийн } & \text { өмнө; } & \text { юуньл } \\
\text { өмнө; } & \text { олньь } & \text { өмнө; } \\
\text { нҮдний } & \text { өмнө; } & \text { тҮҮний } \\
\text { өмнө } & & \\
\end{array}$ & Z өмнө & 189 & 167 & 44 \\
\hline$\sim$ & $\sim$ & $\sim$ & $\sim$ & $\begin{array}{l}\text { өөрийн нь; нүдний нь; } \\
\text { МҮҮний нь; мориньл нь; } \\
\text { ҮҮний нь }\end{array}$ & $Z$ Hb & 143 & 126 & 62 \\
\hline$\sim$ & $\sim$ & $\sim$ & $\sim$ & $\begin{array}{l}\text { гэрийн дотор; зуурын } \\
\text { дотор; түүний дотор; } \\
\text { хүний дотор; сэтгэлийн } \\
\text { дотор; миний дотор; } \\
\text { жилийн дотор }\end{array}$ & Z дотор & 120 & 106 & 76 \\
\hline$\sim$ & $\sim$ & $\sim$ & $\sim$ & $\begin{array}{l}\text { орньл минь; нутгийн } \\
\text { минь; ээжийн минь; } \\
\text { биеийн минь; сэтгэлийн } \\
\text { минь; хҮҮгийн минь; } \\
\text { чиний минь }\end{array}$ & Zминь & 108 & 96 & 80 \\
\hline$\sim$ & $\sim$ & $\sim$ & $\sim$ & $\begin{array}{l}\text { олнь } \text { дунд; харанхуйн } \\
\text { дунд; хүмүҮсийн дунд }\end{array}$ & $Z$ дунд & 53 & 47 & 166 \\
\hline$\sim$ & $\sim$ & $\sim$ & $\sim$ & \begin{tabular}{|l}
$\begin{array}{l}\text { гальин дэргэд; миний } \\
\text { дэргэд }\end{array}$ \\
\end{tabular} & $Z$ дэргэд & 39 & 34 & 234 \\
\hline$\sim$ & $\sim$ & $\sim$ & $\sim$ & юуньл урьд & $Z$ урьд & 31 & 27 & 293 \\
\hline$\sim$ & $\sim$ & $\sim$ & $\sim$ & $\begin{array}{l}\text { жилийн дараа; иагийн } \\
\text { дараа }\end{array}$ & Z дараa & 29 & 26 & 306 \\
\hline$\sim$ & $\sim$ & $\sim$ & $\sim$ & минийл & $Z_{\pi}$ & 16 & 14 & 503 \\
\hline$\sim$ & $\sim$ & $\sim$ & $\sim$ & хэний ч & $Z u$ & 16 & 14 & 504 \\
\hline$\sim$ & $\sim$ & $\sim$ & $\sim$ & өглөөний нар & $Z$ нар & 15 & 13 & 534 \\
\hline$\sim$ & $\sim$ & $\sim$ & $\sim$ & нөхдийн хамт & $Z$ хамт & 15 & 13 & 535 \\
\hline$\sim$ & $\sim$ & $\sim$ & $\sim$ & богдицн хүрээ & $Z$ хурээ & 13 & 11 & 628 \\
\hline$\sim$ & $\sim$ & $\sim$ & $\sim$ & юуньы чинь & $Z$ чинь & 13 & 11 & 629 \\
\hline$\sim$ & $\sim$ & $\sim$ & $\sim$ & тэнгэрийн дор & $Z$ дор & 12 & 11 & 683 \\
\hline$\sim$ & $\sim$ & $\sim$ & $\sim$ & иймийн тул & $Z$ тул & 12 & 11 & 684 \\
\hline$\sim$ & $\sim$ & $\sim$ & $\sim$ & хүний хувь & $Z$ хувь & 12 & 11 & 685 \\
\hline$\sim$ & $\sim$ & $\sim$ & $\sim$ & хүний тухай & $Z$ тухай & 10 & 9 & 828 \\
\hline $\begin{array}{l}\text { GEN-NOM \& } \\
\text { PC.PRF-GEN- } \\
\text { NOM } \\
\end{array}$ & 11 & 10 & 185 & өнгөрсний дараа & $Z$ дараа & 11 & 10 & 743 \\
\hline GEN-NOM & 846 & 747 & 9 & аль хэдийн & аль $Z$ & 77 & 68 & 111 \\
\hline$\sim$ & $\sim$ & $\sim$ & $\sim$ & би өөрийн & би $Z$ & 15 & 13 & 536 \\
\hline$\sim$ & $\sim$ & $\sim$ & $\sim$ & гэх мэтийн & $25 x Z$ & 19 & 17 & 434 \\
\hline$\sim$ & $\sim$ & $\sim$ & $\sim$ & гэж эрдэнийн хэлэхэд & \begin{tabular}{|ll} 
гэж⿻ & $Z$ \\
Хэлэхэд & \\
\end{tabular} & 15 & 13 & 537 \\
\hline$\sim$ & $\sim$ & $\sim$ & $\sim$ & $\begin{array}{l}\text { их тальын; } \\
\text { зохиолчийн; } и x \\
\text { их усньл }\end{array}$ & ux $Z$ & 47 & 42 & 188 \\
\hline$\sim$ & $\sim$ & $\sim$ & $\sim$ & манай нутгийн & манай $Z$ & 12 & 11 & 686 \\
\hline$\sim$ & $\sim$ & $\sim$ & $\sim$ & нөгөө тальын & нөгөө $Z$ & 11 & 10 & 744 \\
\hline$\sim$ & $\sim$ & $\sim$ & $\sim$ & $\begin{array}{l}\text { нэг хүний; нэг ёснығ; нэг } \\
\text { бодльын }\end{array}$ & нэг $Z$ & 47 & 41 & 189 \\
\hline$\sim$ & $\sim$ & $\sim$ & $\sim$ & нэгэн бодльин & нэгэн $Z$ & 14 & 12 & 577 \\
\hline$\sim$ & $\sim$ & $\sim$ & $\sim$ & $\begin{array}{l}\text { олон хүний; олон } \\
\text { жилийн; олон улсьин }\end{array}$ & олон $Z$ & 76 & 68 & 114 \\
\hline$\sim$ & $\sim$ & $\sim$ & $\sim$ & олон жилийн өмнө & олон $Z$ өмнө & 10 & 9 & 829 \\
\hline$\sim$ & $\sim$ & $\sim$ & $\sim$ & та бүхний & $\operatorname{ma} Z$ & 10 & 9 & 830 \\
\hline
\end{tabular}


Oriental Studies. 2019. Is. 5

\begin{tabular}{|c|c|c|c|c|c|c|c|c|}
\hline$\sim$ & $\sim$ & $\sim$ & $\sim$ & $\begin{array}{l}\text { тэр хүний; тэр үеийн; } \\
\text { тэр изагийн; тэр } \\
\text { жилийн; тэр уульлн }\end{array}$ & mэр $Z$ & 89 & 78 & 95 \\
\hline$\sim$ & $\sim$ & $\sim$ & $\sim$ & хэдэн жилийн өмнө & хэдэн Z өмнө & 34 & 30 & 267 \\
\hline$\sim$ & $\sim$ & $\sim$ & $\sim$ & хэн хүний; хэн бүхний & $x \ni \boldsymbol{Z}$ & 23 & 20 & 371 \\
\hline$\sim$ & $\sim$ & $\sim$ & $\sim$ & хэдэн хүний & Хэдэн $Z$ & 10 & 9 & 831 \\
\hline$\sim$ & $\sim$ & $\sim$ & $\sim$ & $\begin{array}{l}\text { энэ хүний; энэ уульын; } \\
\text { энэ хорвоогийн }\end{array}$ & энэ $Z$ & 55 & 48 & 156 \\
\hline GEN-SUBST-NOM & 35 & 30 & 94 & өөрийнх нь; нүднийх нь & $Z$ нь & 35 & 30 & 260 \\
\hline $\begin{array}{l}\text { GEN-SUBST- } \\
\text { POSS.REFL }\end{array}$ & 11 & 10 & 186 & түҮнийхээ дээр & $Z$ дээр & 11 & 10 & 745 \\
\hline GEN/ACC & 175 & 154 & 36 & $\begin{array}{l}\text { сэтгэлий нь; өөрий нь; } \\
\text { гары нь; хөлий нь; биеий } \\
\text { нь; нҮҮрий нь; учры нь; } \\
\text { Үгий нь; гэрий нь; амьl } \\
\text { нь; нэрий нь }\end{array}$ & $Z$ нь & 155 & 136 & 57 \\
\hline$\sim$ & $\sim$ & $\sim$ & $\sim$ & бүхийл & $Z_{\pi}$ & 20 & 18 & 425 \\
\hline $\begin{array}{l}\text { GEN/ACC \& GEN/ } \\
\text { ACC \& PC.DUR- } \\
\text { GEN/ACC }\end{array}$ & 11 & 10 & 187 & бараагий нь & $Z \mathrm{Hb}$ & 11 & 10 & 746 \\
\hline INSTR & 382 & 336 & 23 & зүгээр $Y Y$ & $Z_{Y Y}$ & 12 & 11 & 687 \\
\hline$\sim$ & $\sim$ & $\sim$ & $\sim$ & зүгээр л & $Z \pi$ & 44 & 39 & 207 \\
\hline$\sim$ & $\sim$ & $\sim$ & $\sim$ & $\ddot{е ̈ с о о р ~ н ь ; ~ х ү з ү Ү г э э р ~ н ь ~}$ & $Z \mathrm{Hb}$ & 24 & 21 & 359 \\
\hline$\sim$ & $\sim$ & $\sim$ & $\sim$ & дуугаар хэлэв & $Z$ хэлэв & 46 & 40 & 194 \\
\hline$\sim$ & $\sim$ & $\sim$ & $\sim$ & дуугаар хэлээд & $Z$ хэлээд & 17 & 15 & 482 \\
\hline$\sim$ & $\sim$ & $\sim$ & $\sim$ & нүдээр харж & $Z$ харж & 14 & 12 & 578 \\
\hline$\sim$ & $\sim$ & $\sim$ & $\sim$ & өөрөөр хэлэхэд & $Z$ хэлэхэд & 10 & 9 & 833 \\
\hline$\sim$ & $\sim$ & $\sim$ & $\sim$ & юугаaр ч & $Z$ y & 14 & 12 & 579 \\
\hline$\sim$ & $\sim$ & $\sim$ & $\sim$ & би зүгээр & би $Z$ & 13 & 11 & 630 \\
\hline$\sim$ & $\sim$ & $\sim$ & $\sim$ & гэх зэргээр; гэх мэтээр & $29 x Z$ & 38 & 34 & 239 \\
\hline$\sim$ & $\sim$ & $\sim$ & $\sim$ & нөгөө талаар & нөгев $Z$ & 56 & 49 & 152 \\
\hline$\sim$ & $\sim$ & $\sim$ & $\sim$ & нэг талаар & нэг $Z$ & 29 & 26 & 307 \\
\hline$\sim$ & $\sim$ & $\sim$ & $\sim$ & тэр ёсоор & mэр $Z$ & 21 & 18 & 406 \\
\hline$\sim$ & $\sim$ & $\sim$ & $\sim$ & чи зугээр & чи $Z$ & 19 & 17 & 435 \\
\hline$\sim$ & $\sim$ & $\sim$ & $\sim$ & энэ Үеэр; энэ мэтээр & энэ $Z$ & 25 & 22 & 340 \\
\hline $\begin{array}{l}\text { INSTR-POSS. } \\
\text { REFL } \\
\end{array}$ & 10 & 9 & 207 & би ганияаараа & би $Z$ & 10 & 9 & 832 \\
\hline LAT & 65 & 58 & 67 & ийш тийш & $Z$ тийш & 54 & 48 & 160 \\
\hline$\sim$ & $\sim$ & $\sim$ & $\sim$ & өөр тийи & өөр $Z$ & 11 & 10 & 747 \\
\hline N.PL4A-NOM & 38 & 33 & 91 & ХYYХХYYд минь & $Z$ минь & 23 & 20 & 372 \\
\hline$\sim$ & $\sim$ & $\sim$ & $\sim$ & $x_{Y Y} x \partial Y Y \partial{ }^{\prime}$ & $Z \mathrm{Hb}$ & 15 & 13 & 538 \\
\hline $\begin{array}{l}\text { NOM \& A.COM- } \\
\text { NOM \& DAT }\end{array}$ & 76 & 67 & 59 & та нарт & $m a Z$ & 47 & 41 & 190 \\
\hline$\sim$ & $\sim$ & $\sim$ & $\sim$ & хайрт минь & $Z$ минь & 19 & 17 & 436 \\
\hline$\sim$ & $\sim$ & $\sim$ & $\sim$ & YзуYрт нь & $Z$ Hb & 10 & 9 & 834 \\
\hline NOM \& ABL & 92 & 81 & 50 & араaс нь & $Z$ Hb & 81 & 71 & 104 \\
\hline$\sim$ & $\sim$ & $\sim$ & $\sim$ & түҮний араас & 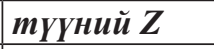 & 11 & 10 & 748 \\
\hline NOM \& ABS-NOM & 571 & 504 & 18 & 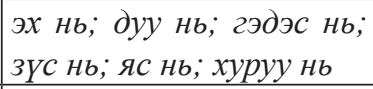 & $Z \mathrm{Hb}$ & 197 & 174 & 43 \\
\hline$\sim$ & $\sim$ & $\sim$ & $\sim$ & $\begin{array}{l}\text { сум шиг; од щиг; сүY } \\
\text { циг; ияас шиг; дуу щиг }\end{array}$ & $Z$ шиг & 85 & 75 & 99 \\
\hline$\sim$ & $\sim$ & $\sim$ & $\sim$ & гэж дуу; гэж хариу & гэю⿻ $Z$ & 70 & 62 & 120 \\
\hline$\sim$ & $\sim$ & $\sim$ & $\sim$ & дуу алдан & $Z$ алдан & 44 & 39 & 208 \\
\hline
\end{tabular}




\begin{tabular}{|c|c|c|c|c|c|c|c|c|}
\hline$\sim$ & $\sim$ & $\sim$ & $\sim$ & $\begin{array}{l}\text { нэг сум; нэг аяга; нэг } \\
\text { шил }\end{array}$ & нэг Z & 34 & 30 & 268 \\
\hline$\sim$ & $\sim$ & $\sim$ & $\sim$ & гэж дуу алдан & гэж $Z$ алдан & 33 & 29 & 277 \\
\hline$\sim$ & $\sim$ & $\sim$ & $\sim$ & юYч; дуyч & $Z u$ & 23 & 20 & 373 \\
\hline$\sim$ & $\sim$ & $\sim$ & $\sim$ & дyy гарч & $Z$ zари & 21 & 18 & 407 \\
\hline$\sim$ & $\sim$ & $\sim$ & $\sim$ & ЮY $6 э$ & $Z_{\boldsymbol{B}}$ & 16 & 14 & 505 \\
\hline$\sim$ & $\sim$ & $\sim$ & $\sim$ & эх болсон & $Z$ болсон & 15 & 13 & 539 \\
\hline$\sim$ & $\sim$ & $\sim$ & $\sim$ & өөр хариу & өөp $Z$ & 11 & 10 & 749 \\
\hline$\sim$ & $\sim$ & $\sim$ & $\sim$ & бага нуур & бага $Z$ & 11 & 10 & 750 \\
\hline$\sim$ & $\sim$ & $\sim$ & $\sim$ & миний эх & миний $Z$ & 11 & 10 & 751 \\
\hline $\begin{array}{l}\text { NOM \& ABS-NOM } \\
\text { \& PC.DUR-NOM \& } \\
\text { POSS.REFL }\end{array}$ & 10 & 9 & 208 & бараа нь & $Z$ нь & 10 & 9 & 835 \\
\hline NOM & 19539 & 17139 & 1 & $\begin{array}{l}\text { Хрээ } Y Y ; \text { тийм } Y Y ; \text { тэр } \\
Y Y ; \text { энэ } Y Y ; x Y^{\prime} Y Y ; Y н э н \\
Y Y\end{array}$ & $Z_{Y Y}$ & 229 & 201 & 33 \\
\hline$\sim$ & $\sim$ & $\sim$ & $\sim$ & тэнгэр өөд; нүүр өөд & $Z \boldsymbol{\theta \theta \partial}$ & 29 & 25 & 310 \\
\hline$\sim$ & $\sim$ & $\sim$ & $\sim$ & ЗУҮн өмнө & $Z$ өмно & 13 & 11 & 644 \\
\hline$\sim$ & $\sim$ & $\sim$ & $\sim$ & $\begin{array}{l}\text { багш аa; ах аа; аав аa; } \\
\text { жанжин аа; найз } а a ; \\
\text { дарга аa }\end{array}$ & Zaa & 138 & 123 & 65 \\
\hline$\sim$ & $\sim$ & $\sim$ & $\sim$ & $\begin{array}{l}\text { хэрэг алга; хүн алга; } \\
\text { арга алга; даанч алга }\end{array}$ & $Z$ алга & 69 & 61 & 124 \\
\hline$\sim$ & $\sim$ & $\sim$ & $\sim$ & $\begin{array}{l}\text { инээд алдан; хөл алдан; } \\
\text { ухаан } \quad \text { алдан; } \quad \text { уулга } \\
\text { алдан }\end{array}$ & $Z$ алдан & 60 & 52 & 139 \\
\hline$\sim$ & $\sim$ & $\sim$ & $\sim$ & аль аль нь & $Z$ аль нь & 14 & 12 & 585 \\
\hline$\sim$ & $\sim$ & $\sim$ & $\sim$ & хүн бөгөөд & $Z$ бөгөөд & 14 & 12 & 586 \\
\hline$\sim$ & $\sim$ & $\sim$ & $\sim$ & энэ бүхэн нь & $Z$ бүхэн нь & 11 & 10 & 763 \\
\hline$\sim$ & $\sim$ & $\sim$ & $\sim$ & $\begin{array}{l}\text { хүн байна; энэ байна; } \\
\text { тийм байна; сайхан } \\
\text { байна; ямар байна; } \\
\text { мэр байна; сайн байна; } \\
\text { бэлэн байна; газар } \\
\text { байна; морь байна; муу } \\
\text { байна; хэрэг байна }\end{array}$ & Z байна & 204 & 181 & 40 \\
\hline$\sim$ & $\sim$ & $\sim$ & $\sim$ & $\begin{array}{l}\text { хүн байлаа; хэрэг } \\
\text { байлаа; тэр байлаа }\end{array}$ & Z байлаа & 58 & 51 & 143 \\
\hline$\sim$ & $\sim$ & $\sim$ & $\sim$ & сайн байна уу & Z байна уу & 46 & 40 & 195 \\
\hline$\sim$ & $\sim$ & $\sim$ & $\sim$ & $\begin{array}{l}\text { mэр байтугай; } \quad x{ }^{H} \\
\text { байтугай }\end{array}$ & Z байтугай & 40 & 36 & 225 \\
\hline$\sim$ & $\sim$ & $\sim$ & $\sim$ & хүн байжээ; энэ байжээ & $Z$ байжээ & 22 & 20 & 385 \\
\hline$\sim$ & $\sim$ & $\sim$ & $\sim$ & тийм байх; хүн байх & $Z$ байx & 20 & 18 & 426 \\
\hline$\sim$ & $\sim$ & $\sim$ & $\sim$ & хүн байсан & Z байсан & 16 & 14 & 507 \\
\hline$\sim$ & $\sim$ & $\sim$ & $\sim$ & хүн байж & $Z$ байж & 15 & 13 & 544 \\
\hline$\sim$ & $\sim$ & $\sim$ & $\sim$ & Хүн байсан юм & Z байсан юм & 11 & 10 & 764 \\
\hline$\sim$ & $\sim$ & $\sim$ & $\sim$ & хүн байна даа & $Z$ байна даа & 10 & 9 & 842 \\
\hline$\sim$ & $\sim$ & $\sim$ & $\sim$ & $\begin{array}{l}\text { ёс бий; } х ү н \text { бий; тийм } \\
\text { бий }\end{array}$ & $Z$ бий & 36 & 31 & 253 \\
\hline$\sim$ & $\sim$ & $\sim$ & $\sim$ & $\begin{array}{l}\text { энэ билээ; тэр билээ; } \\
\text { хүн билээ; сан билээ }\end{array}$ & $Z$ билээ & 80 & 71 & 106 \\
\hline$\sim$ & $\sim$ & $\sim$ & $\sim$ & 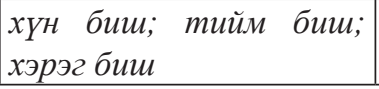 & Z бии & 98 & 86 & 86 \\
\hline
\end{tabular}


Oriental Studies. 2019. Is. 5

\begin{tabular}{|c|c|c|c|c|c|c|c|c|}
\hline$\sim$ & $\sim$ & $\sim$ & $\sim$ & $\begin{array}{l}\text { энэ бол; тэр бол; хүн } \\
\text { бол; тийм бол; сан бол }\end{array}$ & $Z$ бол & 463 & 407 & 13 \\
\hline$\sim$ & $\sim$ & $\sim$ & $\sim$ & $\begin{array}{lr}\text { аль болохоор; } & \text { хүн } \\
\text { болохоор; } & \text { тийм } \\
\text { болохоор } & \\
\end{array}$ & $Z$ болохоор & 94 & 82 & 89 \\
\hline$\sim$ & $\sim$ & $\sim$ & $\sim$ & $\begin{array}{l}\text { хүн болж; тус болж; } \\
u x \text { болж; эр болж; аз } \\
\text { болж }\end{array}$ & Z болюс & 91 & 80 & 92 \\
\hline$\sim$ & $\sim$ & $\sim$ & $\sim$ & $\begin{array}{l}\text { дасал болсон; } \\
\text { болсон; иус болсон }\end{array}$ & $Z$ болсон & 54 & 48 & 161 \\
\hline$\sim$ & $\sim$ & $\sim$ & $\sim$ & $\begin{array}{l}\text { ямар боловч; } \\
\text { боловч; хүн боловч }\end{array}$ & $Z$ боловч & 46 & 40 & 196 \\
\hline$\sim$ & $\sim$ & $\sim$ & $\sim$ & бодол болон & $Z$ болон & 27 & 24 & 327 \\
\hline$\sim$ & $\sim$ & $\sim$ & $\sim$ & тус болох; хүн болох & $Z$ болох & 21 & 19 & 410 \\
\hline$\sim$ & $\sim$ & $\sim$ & $\sim$ & хэрэг болно & $Z$ болно & 18 & 16 & 463 \\
\hline$\sim$ & $\sim$ & $\sim$ & $\sim$ & овогтон болов & $Z$ болов & 15 & 13 & 545 \\
\hline$\sim$ & $\sim$ & $\sim$ & $\sim$ & ияаг боллоо & Z боллоо & 12 & 11 & 698 \\
\hline$\sim$ & $\sim$ & $\sim$ & $\sim$ & том болоод & $Z$ болоод & 11 & 10 & 765 \\
\hline$\sim$ & $\sim$ & $\sim$ & $\sim$ & огт болохгүй & $Z$ болохгуй & 11 & 10 & 766 \\
\hline$\sim$ & $\sim$ & $\sim$ & $\sim$ & хүн болохыг & Z болохыг & 10 & 9 & 843 \\
\hline$\sim$ & $\sim$ & $\sim$ & $\sim$ & $\begin{array}{l}\text { хүн бэ; амьтан бэ; } \\
\text { сайхан бэ }\end{array}$ & $Z$ бэ & 102 & 89 & 84 \\
\hline$\sim$ & $\sim$ & $\sim$ & $\sim$ & $\begin{array}{l}\text { энэ вэ; тэр вэ; аль вэ; } \\
\text { хэрэг вэ; улс вэ; гээ вэ; } \\
\text { золиट вэ; хҮҮхэд вэ }\end{array}$ & $Z \boldsymbol{B}$ & 227 & 201 & 34 \\
\hline$\sim$ & $\sim$ & $\sim$ & $\sim$ & иุарай гарган & $Z$ гарган & 24 & 21 & 362 \\
\hline$\sim$ & $\sim$ & $\sim$ & $\sim$ & xYн гарч & $Z$ zapu & 12 & 11 & 699 \\
\hline$\sim$ & $\sim$ & $\sim$ & $\sim$ & $\begin{array}{l}\text { дүгэр гуай; банди гуай; } \\
\text { шарав гуай; ням гуай; } \\
\text { янжин гуай; өвгөн гуай; } \\
\text { эрдэнэ гуай }\end{array}$ & $Z$ zуай & 102 & 90 & 85 \\
\hline$\sim$ & $\sim$ & $\sim$ & $\sim$ & $m \ni p$ гэх вэ & $Z 25 x 6 э$ & 16 & 14 & 508 \\
\hline$\sim$ & $\sim$ & $\sim$ & $\sim$ & $\begin{array}{l}\text { амьтан даа; яамай даa; } \\
\text { ярииг даа }\end{array}$ & $Z$ дaa & 40 & 35 & 226 \\
\hline$\sim$ & $\sim$ & $\sim$ & $\sim$ & мэртээ дор & $Z$ дор & 10 & 9 & 844 \\
\hline$\sim$ & $\sim$ & $\sim$ & $\sim$ & $\begin{array}{l}\text { тэр дунд; шөнө дунд; } \\
\text { өдөр дунд; бага дунд }\end{array}$ & $Z$ дунд & 69 & 61 & 125 \\
\hline$\sim$ & $\sim$ & $\sim$ & $\sim$ & 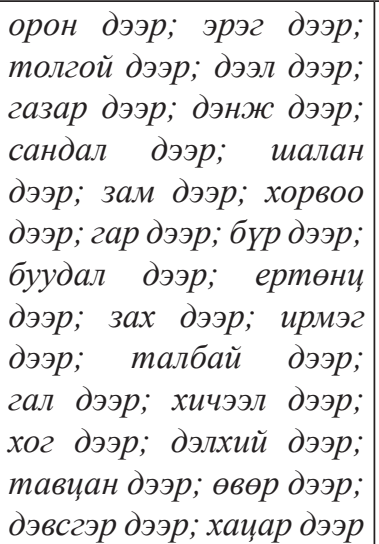 & $Z$ дээр & 469 & 413 & 12 \\
\hline
\end{tabular}




\begin{tabular}{|c|c|c|c|c|c|c|c|c|}
\hline$\sim$ & $\sim$ & $\sim$ & $\sim$ & $\mid \begin{array}{lrr}\text { орон дээрээ; хөл } & \text { өээрэээ; } \\
\text { өвдег } & \text { дээрээ; } & \text { өвөр } \\
\text { дээрээ; } & \text { гар } & \text { дээрээ; } \\
\text { эмээл } & \text { дээрээ; } & \text { толгой } \\
\text { дээрээ; } \text { хэрэг дэрэээ }\end{array}$ & $Z$ дээрээ & 168 & 148 & 50 \\
\hline$\sim$ & $\sim$ & $\sim$ & $\sim$ & $\begin{array}{l}\text { хүн дээ; тийм дээ; энэ } \\
\text { дээ; mэр дээ; хэрэг дээ }\end{array}$ & $Z$ дээ & 129 & 114 & 69 \\
\hline$\sim$ & $\sim$ & $\sim$ & $\sim$ & толгой дээр нь & $Z$ дээр нь & 11 & 10 & 767 \\
\hline$\sim$ & $\sim$ & $\sim$ & $\sim$ & хүн ирж & $Z$ ирж⿻ & 17 & 15 & 484 \\
\hline$\sim$ & $\sim$ & $\sim$ & $\sim$ & өдөр ирэх & $Z$ ирэх & 13 & 11 & 645 \\
\hline$\sim$ & $\sim$ & $\sim$ & $\sim$ & $\begin{array}{l}\text { их л; дэмий л; төдий л; } \\
\text { тэр л; ийм л; энэ л; арай } \\
л ; \text { улам л; аанай л; тийм } \\
л ; \text { хүн л; өнөөх л; зөвхөн } \\
л ; \text { нээрээ л; хоёр л; иөөм } \\
л ; \text { бүх л; чухам л; нөгөө } \\
л\end{array}$ & $Z_{\pi}$ & 802 & 706 & 5 \\
\hline$\sim$ & $\sim$ & $\sim$ & $\sim$ & тийм л дээ & $Z_{\text {л дээ }}$ & 13 & 11 & 646 \\
\hline$\sim$ & $\sim$ & $\sim$ & $\sim$ & 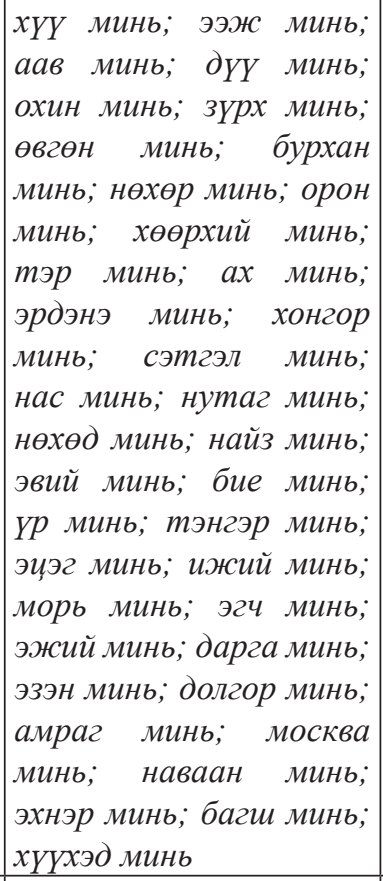 & Zминь & 1338 & 1178 & 2 \\
\hline$\sim$ & $\sim$ & $\sim$ & $\sim$ & сайн мэднэ & 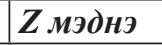 & 35 & 31 & 262 \\
\hline$\sim$ & $\sim$ & $\sim$ & $\sim$ & энэ мэт; буй мэт & $Z_{\text {мэm }}$ & 40 & 35 & 227 \\
\hline$\sim$ & $\sim$ & $\sim$ & $\sim$ & $\begin{array}{l}\text { лам нар; дүҮ нар; дарга } \\
\text { нар; шар нар; багш нар; } \\
\text { ач нар; хури нар }\end{array}$ & $Z$ нap & 151 & 134 & 59 \\
\hline$\sim$ & $\sim$ & $\sim$ & $\sim$ & $\begin{array}{l}\text { лам нарын; багш нарын; } \\
\text { дарга нарын }\end{array}$ & Z нарын & 54 & 48 & 162 \\
\hline
\end{tabular}




\begin{tabular}{|c|c|c|c|c|c|c|c|c|}
\hline$\sim$ & $\sim$ & $\sim$ & $\sim$ & 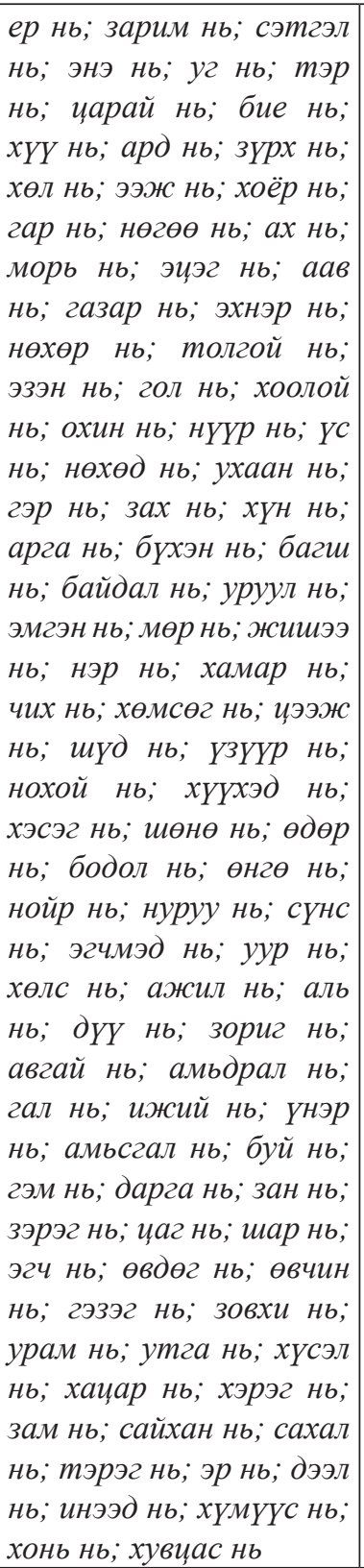 & 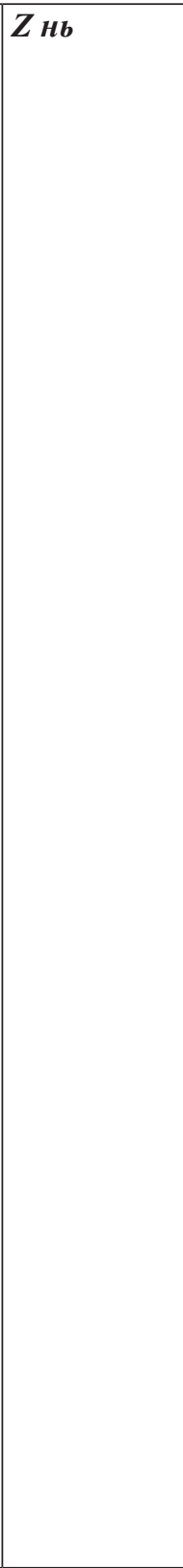 & 3993 & 3516 & 1 \\
\hline$\sim$ & $\sim$ & $\sim$ & $\sim$ & аль ньч & $Z$ ньч & 13 & 11 & 647 \\
\hline$\sim$ & $\sim$ & $\sim$ & $\sim$ & ер ньл & $Z$ ньл & 12 & 11 & 700 \\
\hline$\sim$ & $\sim$ & $\sim$ & $\sim$ & энэ нь бол & $Z$ нь бол & 11 & 10 & 768 \\
\hline$\sim$ & $\sim$ & $\sim$ & $\sim$ & ямар нэг юм & $Z$ нэг юм & 19 & 17 & 440 \\
\hline$\sim$ & $\sim$ & $\sim$ & $\sim$ & зарим нэг нь & $Z$ нэг нь & 15 & 13 & 546 \\
\hline$\sim$ & $\sim$ & $\sim$ & $\sim$ & ямар нэгэн юм & $Z$ нэгэн юм & 15 & 13 & 547 \\
\hline$\sim$ & $\sim$ & $\sim$ & $\sim$ & ухаан орж & $Z$ оржс & 12 & 11 & 701 \\
\hline$\sim$ & $\sim$ & $\sim$ & $\sim$ & $Y Y \partial p_{Y Y ;}$ эрэг $p_{Y Y}$ & $Z_{p Y Y}$ & 25 & 22 & 344 \\
\hline$\sim$ & $\sim$ & $\sim$ & $\sim$ & нүҮр рүҮ нь & $Z_{p Y Y} \boldsymbol{\mu b}$ & 10 & 9 & 845 \\
\hline$\sim$ & $\sim$ & $\sim$ & $\sim$ & $\begin{array}{l}\text { хот руу; зах руу; толгой } \\
\text { руу }\end{array}$ & Z pyy & 36 & 32 & 254 \\
\hline$\sim$ & $\sim$ & $\sim$ & $\sim$ & $\begin{array}{l}\text { зуҮн тальын; баруун } \\
\text { тальлн; хоёр тальлн }\end{array}$ & Z тальн & 72 & 63 & 117 \\
\hline$\sim$ & $\sim$ & $\sim$ & $\sim$ & $\begin{array}{ll}\text { баруун талд; } \\
\text { талд; хоёр түлд }\end{array}$ & Z талд & 41 & 37 & 219 \\
\hline$\sim$ & $\sim$ & $\sim$ & $\sim$ & изагаан тал; дах тал & $Z$ тал & 27 & 24 & 328 \\
\hline
\end{tabular}




\begin{tabular}{|c|c|c|c|c|c|c|c|c|}
\hline$\sim$ & $\sim$ & $\sim$ & $\sim$ & зуҮн талаар & $Z$ талаар & 10 & 9 & 846 \\
\hline$\sim$ & $\sim$ & $\sim$ & $\sim$ & $\begin{array}{l}\text { баруун тийш; } \\
\text { тийш; хоёр тийш }\end{array}$ & $Z$ тийш & 48 & 42 & 184 \\
\hline$\sim$ & $\sim$ & $\sim$ & $\sim$ & хүн тул & $Z$ тул & 13 & 11 & 648 \\
\hline$\sim$ & $\sim$ & $\sim$ & $\sim$ & энэ тухай; тэр тухай & $Z$ myхай & 57 & 50 & 147 \\
\hline$\sim$ & $\sim$ & $\sim$ & $\sim$ & $\begin{array}{l}\text { энэ удаа; олон удаa; } \\
\text { хоёр удаа; эиссийн удаa }\end{array}$ & Zydaa & 126 & 110 & 70 \\
\hline$\sim$ & $\sim$ & $\sim$ & $\sim$ & энэ удаа ч & Zyдаa ч & 10 & 9 & 847 \\
\hline$\sim$ & $\sim$ & $\sim$ & $\sim$ & сайн уу & $Z y y$ & 21 & 18 & 411 \\
\hline$\sim$ & $\sim$ & $\sim$ & $\sim$ & том хүрэн & 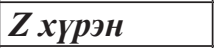 & 17 & 15 & 485 \\
\hline$\sim$ & $\sim$ & $\sim$ & $\sim$ & өдий хүртэл & 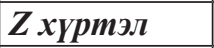 & 14 & 12 & 587 \\
\hline$\sim$ & $\sim$ & $\sim$ & $\sim$ & буруу харж & $Z$ харюс & 15 & 13 & 548 \\
\hline$\sim$ & $\sim$ & $\sim$ & $\sim$ & $\begin{array}{l}\text { хоол хийж; ажил хийж; } \\
\text { цай хийж }\end{array}$ & $Z$ хийэс & 70 & 62 & 121 \\
\hline$\sim$ & $\sim$ & $\sim$ & $\sim$ & нөгөө хоёр нь & $Z$ хоёр нь & 12 & 11 & 702 \\
\hline$\sim$ & $\sim$ & $\sim$ & $\sim$ & баруун хойноос & $Z$ хойноос & 11 & 10 & 769 \\
\hline$\sim$ & $\sim$ & $\sim$ & $\sim$ & баруун хойм & $Z$ хойш & 11 & 10 & 770 \\
\hline$\sim$ & $\sim$ & $\sim$ & $\sim$ & 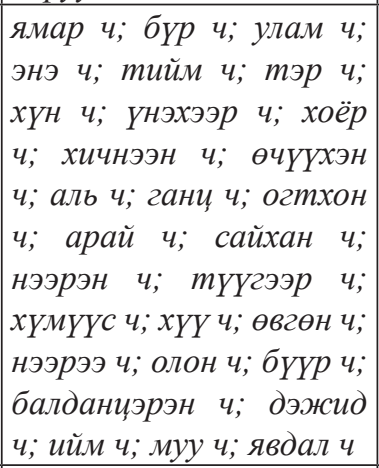 & $\begin{array}{ll}\boldsymbol{u} \\
\end{array}$ & 1141 & 1003 & 3 \\
\hline$\sim$ & $\sim$ & $\sim$ & $\sim$ & тэр ч байтугай & $\begin{array}{|lr|}Z & 4 \\
\text { байтугай } & \\
\end{array}$ & 40 & 35 & 228 \\
\hline$\sim$ & $\sim$ & $\sim$ & $\sim$ & ямар ч байсан & Z ч байсан & 18 & 16 & 464 \\
\hline$\sim$ & $\sim$ & $\sim$ & $\sim$ & тэр ч яахав & Zч яахав & 12 & 11 & 703 \\
\hline$\sim$ & $\sim$ & $\sim$ & $\sim$ & $\begin{array}{l}\text { энэ чинь; тэр чинь; аав } \\
\text { чинь; өвгөн чинь; хүY } \\
\text { чинь; хүн чинь; ах чинь; } \\
\text { бие чинь; нөхөр чинь; } \\
\text { ээж чинь; эцээ чинь }\end{array}$ & $Z$ чинь & 511 & 448 & 11 \\
\hline$\sim$ & $\sim$ & $\sim$ & $\sim$ & $\begin{array}{l}\text { хүн шүY; амьтан шүY; } \\
\text { сайхан шүY }\end{array}$ & $Z \omega_{Y Y}$ & 69 & 61 & 126 \\
\hline$\sim$ & $\sim$ & $\sim$ & $\sim$ & $\begin{array}{llll}x Y н & \text { шүY } \text { дээ; амьтан } \\
\text { шуY дээ } & \end{array}$ & $Z$ шиY дээ & 45 & 40 & 202 \\
\hline$\sim$ & $\sim$ & $\sim$ & $\sim$ & 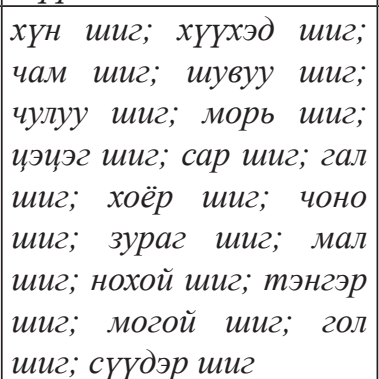 & Z uиz & 427 & 378 & 16 \\
\hline$\sim$ & $\sim$ & $\sim$ & $\sim$ & $\begin{array}{l}\text { тийм ээ; ээж ээ; хэрэг } \\
\text { ээ; тэр ээ }\end{array}$ & $Z$ ээ & 238 & 209 & 31 \\
\hline
\end{tabular}


Oriental Studies. 2019. Is. 5

\begin{tabular}{|c|c|c|c|c|c|c|c|c|}
\hline$\sim$ & $\sim$ & $\sim$ & $\sim$ & $\begin{array}{l}\text { бүх юм; өөр юм; хүн } \\
\text { юм; их юм; сайхан юм; } \\
\text { муу юм; олон юм; тийм } \\
\text { юм; ийм юм; дэмий } \\
\text { юм; сонин юм; улс юм; } \\
\text { амьтан юм; хачин юм; } \\
\text { хэичу юм; сайн юм; } \\
\text { хамаг юм }\end{array}$ & Z юм & 399 & 352 & 18 \\
\hline$\sim$ & $\sim$ & $\sim$ & $\sim$ & хүн юм даа; эр юм даа & $Z$ юм даа & 24 & 21 & 363 \\
\hline$\sim$ & $\sim$ & $\sim$ & $\sim$ & ихэр юм шиг & Z юм шиг & 11 & 10 & 771 \\
\hline$\sim$ & $\sim$ & $\sim$ & $\sim$ & сайн явж байна уу & $\begin{array}{l}Z \text { явж байна } \\
y y\end{array}$ & 10 & 9 & 848 \\
\hline$\sim$ & $\sim$ & $\sim$ & $\sim$ & зүг явлаа & Z явлаа & 16 & 14 & 509 \\
\hline$\sim$ & $\sim$ & $\sim$ & $\sim$ & өөр ямар ч & $Z$ ямар ч & 15 & 13 & 549 \\
\hline NOM \& CAR-NOM & 56 & 49 & 72 & аягүй бол & $Z$ бол & 56 & 49 & 153 \\
\hline $\begin{array}{l}\text { NOM \& CAR- } \\
\text { NOM \& PC.US- } \\
\text { CAR-NOM }\end{array}$ & 26 & 23 & 115 & болдоггуй юм & Z юм & 26 & 23 & 333 \\
\hline NOM \& CAR-NOM & 56 & 49 & 72 & чимээгүй болов & $Z$ болов & 15 & 13 & 540 \\
\hline$\sim$ & $\sim$ & $\sim$ & $\sim$ & гайгүй ээ & $Z$ ээ & 15 & 13 & 541 \\
\hline $\begin{array}{l}\text { NOM \& CAR-NOM } \\
\text { \& CAR-NOM }\end{array}$ & 13 & 11 & 167 & бүсгуй минь & Zминь & 13 & 11 & 631 \\
\hline NOM \& CAR-NOM & 56 & 49 & 72 & сураггүй алга & $Z$ алга & 11 & 10 & 752 \\
\hline $\begin{array}{l}\text { NOM \& COM- } \\
\text { NOM }\end{array}$ & 98 & 87 & 47 & $\begin{array}{l}\text { гэсэн янзтай; гэсэн } \\
\text { утгатай }\end{array}$ & гэсэн $Z$ & 25 & 22 & 341 \\
\hline$\sim$ & $\sim$ & $\sim$ & $\sim$ & золтойл & $Z_{\pi}$ & 23 & 20 & 374 \\
\hline$\sim$ & $\sim$ & $\sim$ & $\sim$ & харамсалтай нь & $Z$ Hb & 14 & 12 & 580 \\
\hline$\sim$ & $\sim$ & $\sim$ & $\sim$ & сүртээй бөгөөд & $Z$ бөгөөд & 12 & 11 & 688 \\
\hline$\sim$ & $\sim$ & $\sim$ & $\sim$ & өөр хүнтэй & өөр $Z$ & 12 & 11 & 689 \\
\hline$\sim$ & $\sim$ & $\sim$ & $\sim$ & би хайртай & би $Z$ & 12 & 11 & 690 \\
\hline NOM \& CVB.ANT & 57 & 50 & 70 & дахиадл & $Z_{\pi}$ & 57 & 50 & 146 \\
\hline $\begin{array}{l}\text { NOM \& CVB. } \\
\text { CNGR }\end{array}$ & 13 & 11 & 168 & чингэж байтал & Z байтал & 13 & 11 & 632 \\
\hline NOM \& CVB.MOD & 162 & 142 & 38 & гэж бодон; гэж яаран & гэюж $Z$ & 162 & 142 & 55 \\
\hline NOM \& DAT & 381 & 337 & 24 & $\begin{array}{l}\text { эијэст нь; хариуд нь; } \\
\text { сҮҮлд нb; эзэд нь }\end{array}$ & $Z$ Hb & 310 & 273 & 26 \\
\hline$\sim$ & $\sim$ & $\sim$ & $\sim$ & шуудд л & $Z_{\pi}$ & 18 & 16 & 460 \\
\hline$\sim$ & $\sim$ & $\sim$ & $\sim$ & бүргэд шиг & $Z$ шиг & 12 & 11 & 692 \\
\hline$\sim$ & $\sim$ & $\sim$ & $\sim$ & шууд явсаар & $Z$ явсаар & 11 & 10 & 753 \\
\hline$\sim$ & $\sim$ & $\sim$ & $\sim$ & анд минь & $Z$ минь & 10 & 9 & 836 \\
\hline$\sim$ & $\sim$ & $\sim$ & $\sim$ & хойд тальын & $Z$ тальин & 10 & 9 & 837 \\
\hline$\sim$ & $\sim$ & $\sim$ & $\sim$ & унд хийж & $Z$ хийюс & 10 & 9 & 838 \\
\hline $\begin{array}{l}\text { NOM \& DAT \& } \\
\text { CVB.ANT }\end{array}$ & 12 & 11 & 175 & ахиад л & $Z_{\pi}$ & 12 & 11 & 691 \\
\hline $\begin{array}{l}\text { NOM \& DAT \& } \\
\text { DAT }\end{array}$ & 25 & 22 & 117 & хамгийн түрҮҮнд & хамгийн $Z$ & 25 & 22 & 342 \\
\hline NOM \& DAT & 381 & 337 & 24 & гэж шууд & гэю⿻ $Z$ & 12 & 11 & 693 \\
\hline $\begin{array}{l}\text { NOM \& DAT- } \\
\text { POSS.REFL } \\
\end{array}$ & 28 & 25 & 110 & тэр мөртөө & $m э p Z$ & 28 & 25 & 318 \\
\hline NOM \& GEN-NOM & 220 & 194 & 31 & $\begin{array}{l}\text { эдний дунд; зуньл дунд; } \\
\text { намрьин дунд }\end{array}$ & $Z$ дунд & 35 & 31 & 261 \\
\hline$\sim$ & $\sim$ & $\sim$ & $\sim$ & $\begin{array}{l}\text { насньл минь; төрийн } \\
\text { минь }\end{array}$ & $Z$ минь & 34 & 30 & 269 \\
\hline
\end{tabular}




\begin{tabular}{|c|c|c|c|c|c|c|c|c|}
\hline$\sim$ & $\sim$ & $\sim$ & $\sim$ & $\begin{array}{l}\text { хэдэн өдрийн дараа; } \\
\text { хэдэн хоногийн дараа }\end{array}$ & \begin{tabular}{|l|} 
Хэдэн \\
дараа
\end{tabular} & 34 & 30 & 270 \\
\hline$\sim$ & $\sim$ & $\sim$ & $\sim$ & $\begin{array}{l}\text { хоногийн өмнө; толиньл } \\
\text { өмнө }\end{array}$ & Z өмно & 33 & 29 & 278 \\
\hline$\sim$ & $\sim$ & $\sim$ & $\sim$ & хоногийн дараа & $Z$ дараa & 29 & 26 & 308 \\
\hline$\sim$ & $\sim$ & $\sim$ & $\sim$ & энэ өдрийн; энэ айльын & энэ $Z$ & 28 & 24 & 319 \\
\hline$\sim$ & $\sim$ & $\sim$ & $\sim$ & их сургуулийн; их бууньл & $u x Z$ & 27 & 24 & 326 \\
\hline $\begin{array}{l}\text { NOM \& GEN-NOM } \\
\text { \& REL-GEN-NOM }\end{array}$ & 21 & 18 & 132 & их мөрний & $u x Z$ & 21 & 18 & 408 \\
\hline NOM \& GEN-NOM & 220 & 194 & 31 & мэр өдрийн & mэр $Z$ & 21 & 18 & 409 \\
\hline $\begin{array}{l}\text { NOM \& GEN-NOM } \\
\text { \& CVB.MOD }\end{array}$ & 19 & 17 & 136 & гүйн ирж & $Z$ иржс & 19 & 17 & 437 \\
\hline $\begin{array}{l}\text { NOM \& GEN-NOM } \\
\text { \& GEN-NOM }\end{array}$ & 18 & 16 & 141 & манай ангийн & манай $Z$ & 18 & 16 & 461 \\
\hline NOM \& GEN-NOM & 220 & 194 & 31 & хоногийн дотор & $Z$ дотор & 18 & 16 & 462 \\
\hline$\sim$ & $\sim$ & $\sim$ & $\sim$ & сарны дор & $Z$ дор & 17 & 15 & 483 \\
\hline$\sim$ & $\sim$ & $\sim$ & $\sim$ & хэдэн өдрийн & хэдэн $Z$ & 14 & 12 & 581 \\
\hline $\begin{array}{l}\text { NOM \& GEN-NOM } \\
\text { \& GEN-NOM }\end{array}$ & 18 & 16 & 141 & олон өнгийн & олон $Z$ & 13 & 11 & 633 \\
\hline NOM \& GEN-NOM & 220 & 194 & 31 & бага үдийн & бага $Z$ & 13 & 11 & 634 \\
\hline$\sim$ & $\sim$ & $\sim$ & $\sim$ & хэд хоногийн дараа & хэд Z дараa & 13 & 11 & 635 \\
\hline $\begin{array}{l}\text { NOM \& GEN-NOM } \\
\text { \& CVB.MOD }\end{array}$ & 19 & 17 & 136 & гүйн очиж & Z очиж & 12 & 11 & 694 \\
\hline NOM \& GEN-NOM & 220 & 194 & 31 & амьдралььн тухай & $Z$ mухай & 11 & 10 & 754 \\
\hline NOM \& INSTR & 10 & 9 & 209 & амьдаар нь & $Z$ Hb & 10 & 9 & 839 \\
\hline $\begin{array}{l}\text { NOM \& INSTR- } \\
\text { POSS.REFL }\end{array}$ & 23 & 20 & 126 & mэр чигээрээ & mэр $Z$ & 23 & 20 & 375 \\
\hline $\begin{array}{l}\text { NOM \& PC.DUR- } \\
\text { CAR-NOM }\end{array}$ & 11 & 10 & 190 & амжаагүй байтал & Z байтал & 11 & 10 & 755 \\
\hline $\begin{array}{l}\text { NOM \& PC.PRF- } \\
\text { NOM }\end{array}$ & 66 & 58 & 64 & миний төрсөн & миний $Z$ & 29 & 26 & 309 \\
\hline$\sim$ & $\sim$ & $\sim$ & $\sim$ & төрсөн минь & $Z$ минь & 13 & 11 & 636 \\
\hline$\sim$ & $\sim$ & $\sim$ & $\sim$ & өнгөрсөн хойно & $Z$ хойно & 13 & 11 & 637 \\
\hline$\sim$ & $\sim$ & $\sim$ & $\sim$ & үлдсэн юм & $Z$ юм & 11 & 10 & 756 \\
\hline $\begin{array}{|lll|}\text { NOM } & \& & \text { PC.US- } \\
\text { NOM } & & \\
\end{array}$ & 47 & 42 & 85 & болдог юм & Z юм & 25 & 22 & 343 \\
\hline$\sim$ & $\sim$ & $\sim$ & $\sim$ & болдог билээ & $Z$ билээ & 11 & 10 & 757 \\
\hline$\sim$ & $\sim$ & $\sim$ & $\sim$ & болдог юм бэ & $Z$ юм бэ & 11 & 10 & 758 \\
\hline \begin{tabular}{lll|} 
NOM & $\&$ & POSS. \\
REFL & & \\
\end{tabular} & 83 & 71 & 55 & лугаа адил & $Z$ адил & 30 & 26 & 302 \\
\hline$\sim$ & $\sim$ & $\sim$ & $\sim$ & $\theta в \theta \theta ~ н ь$ & $Z$ нь & 14 & 12 & 582 \\
\hline$\sim$ & $\sim$ & $\sim$ & $\sim$ & аль хэдийнээ & аль $Z$ & 13 & 11 & 638 \\
\hline$\sim$ & $\sim$ & $\sim$ & $\sim$ & гээд дулмаа & гээд $Z$ & 13 & 11 & 639 \\
\hline$\sim$ & $\sim$ & $\sim$ & $\sim$ & тэр тусмаа & mэр $Z$ & 13 & 11 & 640 \\
\hline $\begin{array}{l}\text { NOM \& POSS. } \\
\text { REFL \& VF.IND. } \\
\text { PROF-EMPH }\end{array}$ & 12 & 11 & 178 & их баярлалаа & $u x Z$ & 12 & 11 & 695 \\
\hline $\begin{array}{l}\text { NOM \& POSS. } \\
\text { REFL }\end{array}$ & 83 & 71 & 55 & согоо шиг & $Z$ шиг & 12 & 11 & 696 \\
\hline NOM \& REL-NOM & 90 & 80 & 52 & хамгийн түрҮүн & хамгийн $Z$ & 33 & 29 & 279 \\
\hline \begin{tabular}{l|l}
$\sim$ \\
\end{tabular} & $\sim$ & $\sim$ & $\sim$ & мөрөн дээр; элсэн дээр & $Z$ дээр & 24 & 22 & 360 \\
\hline$\sim$ & $\sim$ & $\sim$ & $\sim$ & мөрөн дээрээ & $Z$ дээрээ & 19 & 17 & 438 \\
\hline$\sim$ & $\sim$ & $\sim$ & $\sim$ & гэж чулуун & гэю⿻ $Z$ & 14 & 12 & 583 \\
\hline
\end{tabular}


Oriental Studies. 2019. Is. 5

\begin{tabular}{|c|c|c|c|c|c|c|c|c|}
\hline $\begin{array}{l}\text { NOM \& REL-NOM } \\
\text { \& CVB.MOD }\end{array}$ & 11 & 10 & 191 & тосон авч & $Z$ abu & 11 & 10 & 759 \\
\hline NOM \& REL-NOM & 90 & 80 & 52 & чулуун минь & $Z$ минь & 11 & 10 & 760 \\
\hline $\begin{array}{l}\text { NOM \& VF.IND. } \\
\text { AOR }\end{array}$ & 13 & 11 & 170 & элдэв юм & $Z$ юм & 13 & 11 & 641 \\
\hline $\begin{array}{l}\text { NOM \& VF.OPT. } \\
\text { JUSS }\end{array}$ & 43 & 38 & 89 & барагл & $Z_{\pi}$ & 43 & 38 & 210 \\
\hline $\begin{array}{l}\text { NOM \& VF.OPT. } \\
\text { IMP }\end{array}$ & 187 & 165 & 35 & aй дaa & $Z$ даa & 40 & 35 & 224 \\
\hline$\sim$ & $\sim$ & $\sim$ & $\sim$ & битаий хэл & битгий $Z$ & 33 & 29 & 280 \\
\hline$\sim$ & $\sim$ & $\sim$ & $\sim$ & бүY хэл & $\sigma_{Y Y} Z$ & 32 & 28 & 286 \\
\hline$\sim$ & $\sim$ & $\sim$ & $\sim$ & хар юм & $Z$ юм & 24 & 21 & 361 \\
\hline$\sim$ & $\sim$ & $\sim$ & $\sim$ & гэж хэл; гэж хар & гэю⿻ $Z$ & 23 & 21 & 376 \\
\hline$\sim$ & $\sim$ & $\sim$ & $\sim$ & mac xap & $\operatorname{mac} Z$ & 19 & 17 & 439 \\
\hline$\sim$ & $\sim$ & $\sim$ & $\sim$ & нэг хар & нэг $Z$ & 16 & 14 & 506 \\
\hline $\begin{array}{l}\text { NOM \& VF.OPT. } \\
\text { IMP \& ABS-NOM }\end{array}$ & 15 & 13 & 152 & ux буy & $u x Z$ & 15 & 13 & 542 \\
\hline $\begin{array}{l}\text { NOM \& VF.OPT. } \\
\text { IMP }\end{array}$ & 187 & 165 & 35 & энэ хар & энэ $Z$ & 15 & 13 & 543 \\
\hline$\sim$ & $\sim$ & $\sim$ & $\sim$ & хэл нь & $Z$ Hb & 13 & 11 & 642 \\
\hline$\sim$ & $\sim$ & $\sim$ & $\sim$ & бага сага & бага $Z$ & 13 & 11 & 643 \\
\hline$\sim$ & $\sim$ & $\sim$ & $\sim$ & mэр хар & mэр $Z$ & 12 & 11 & 697 \\
\hline $\begin{array}{l}\text { NOM \& VF.OPT. } \\
\text { IMP \& DAT }\end{array}$ & 11 & 10 & 193 & хамгийн сүүлд & хамгийн $Z$ & 11 & 10 & 761 \\
\hline $\begin{array}{l}\text { NOM \& VF.OPT. } \\
\text { IMP }\end{array}$ & 187 & 165 & 35 & хэл мэдэхгүй & $Z$ Ммэдэхгуй & 11 & 10 & 762 \\
\hline $\begin{array}{l}\text { NOM \& VF.OPT. } \\
\text { IMP \& A.COM- } \\
\text { NOM \& DAT }\end{array}$ & 10 & 9 & 210 & миний хайрт & миний $Z$ & 10 & 9 & 840 \\
\hline $\begin{array}{l}\text { NOM \& VF.OPT. } \\
\text { JUSS }\end{array}$ & 43 & 38 & 89 & гэж бараг & гэж $Z$ & 10 & 9 & 841 \\
\hline NOM & 19539 & 17139 & 1 & өөр хүн; өөр арга & өөp $Z$ & 38 & 34 & 240 \\
\hline$\sim$ & $\sim$ & $\sim$ & $\sim$ & өнөөх хүн & өнөөх $Z$ & 10 & 9 & 849 \\
\hline$\sim$ & $\sim$ & $\sim$ & $\sim$ & $\begin{array}{l}\text { бүх бие; бүх гэр; бүх } \\
\text { иэрэг }\end{array}$ & $\sigma_{Y} x Z$ & 34 & 30 & 271 \\
\hline$\sim$ & $\sim$ & $\sim$ & $\sim$ & бүх бие нь & $\sigma_{Y x} Z \boldsymbol{\mu b}$ & 24 & 21 & 364 \\
\hline$\sim$ & $\sim$ & $\sim$ & $\sim$ & бүрэн эрхт & бүрэн $Z$ & 15 & 13 & 550 \\
\hline$\sim$ & $\sim$ & $\sim$ & $\sim$ & бага зэрэг; бага балчир & бага $Z$ & 42 & 37 & 215 \\
\hline$\sim$ & $\sim$ & $\sim$ & $\sim$ & $\begin{array}{l}\text { бас чингис; бас дахин; } \\
\text { бас хоёр }\end{array}$ & бас $Z$ & 60 & 53 & 140 \\
\hline$\sim$ & $\sim$ & $\sim$ & $\sim$ & би хүн; би хоёр & би $Z$ & 27 & 24 & 329 \\
\hline$\sim$ & $\sim$ & $\sim$ & $\sim$ & би ер нь & би $Z$ нь & 17 & 15 & 486 \\
\hline$\sim$ & $\sim$ & $\sim$ & $\sim$ & би гэдэг хүн & би гэдэг $Z$ & 17 & 15 & 487 \\
\hline$\sim$ & $\sim$ & $\sim$ & $\sim$ & бид хоёр & бид $Z$ & 300 & 264 & 27 \\
\hline$\sim$ & $\sim$ & $\sim$ & $\sim$ & битгий уйл & битгий $Z$ & 10 & 9 & 850 \\
\hline$\sim$ & $\sim$ & $\sim$ & $\sim$ & бор морь & бор $Z$ & 25 & 22 & 345 \\
\hline$\sim$ & $\sim$ & $\sim$ & $\sim$ & $\begin{array}{l}\text { гани хоёр; гани бие; } \\
\text { гани хүн; ганиц хүY }\end{array}$ & ганц Z & 67 & 59 & 129 \\
\hline$\sim$ & $\sim$ & $\sim$ & $\sim$ & $\begin{array}{l}\text { гэвч балданцэрэн; гэвч } \\
\text { хүн }\end{array}$ & гэвч $Z$ & 32 & 28 & 287 \\
\hline$\sim$ & $\sim$ & $\sim$ & $\sim$ & $\begin{array}{l}\text { гэдэг газар; гэдэг бодол; } \\
\text { гэдэг хүн; гэдэг амьтан; } \\
\text { гэдэг нэр }\end{array}$ & гэдэг Z & 114 & 101 & 78 \\
\hline
\end{tabular}




\begin{tabular}{|c|c|c|c|c|c|c|c|c|}
\hline$\sim$ & $\sim$ & $\sim$ & $\sim$ & 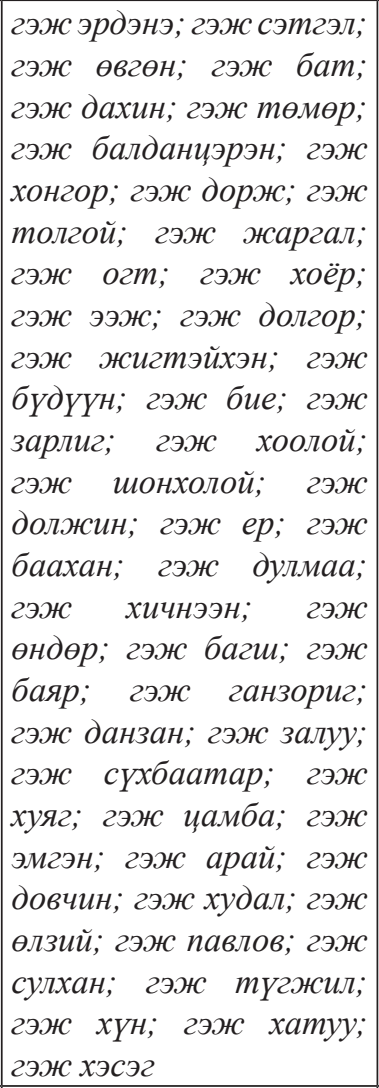 & гэю⿻ $Z$ & 869 & 768 & 4 \\
\hline$\sim$ & $\sim$ & $\sim$ & $\sim$ & гэж зарлиг болов & гэж⿻ $Z$ болов & 72 & 63 & 118 \\
\hline$\sim$ & $\sim$ & $\sim$ & $\sim$ & гэж эрдэнэ хэлэв & гэюк $Z$ хэлэв & 14 & 12 & 588 \\
\hline$\sim$ & $\sim$ & $\sim$ & $\sim$ & гэсэн бодол; гэсэн хэрэг & гэсэн $Z$ & 54 & 47 & 163 \\
\hline$\sim$ & $\sim$ & $\sim$ & $\sim$ & гэтэл нэг өдөр & гэтэл нэг $Z$ & 12 & 11 & 704 \\
\hline$\sim$ & $\sim$ & $\sim$ & $\sim$ & гэх зэрэг & $25 x Z$ & 34 & 30 & 272 \\
\hline$\sim$ & $\sim$ & $\sim$ & $\sim$ & гэхэд өвгөн; гэхэд хуY & гэхэд $Z$ & 31 & 27 & 294 \\
\hline$\sim$ & $\sim$ & $\sim$ & $\sim$ & $\begin{array}{l}\text { гээд эрдэнэ; гээд төмөр; } \\
\text { гээд бат; гээд хонгор; } \\
\text { гээд жаргал; гээд гэрэл; } \\
\text { гээд өвгөн; гээд дахин; } \\
\text { гээд жамбал; гээд } \\
\text { петр; гээд сүхбаатар; } \\
\text { гээд түгжил }\end{array}$ & 2ээठ $Z$ & 214 & 188 & 39 \\
\hline$\sim$ & $\sim$ & $\sim$ & $\sim$ & $\begin{array}{l}\text { зарим хүмүус; зарим } \\
\text { газар; зарим хүн }\end{array}$ & зарим $Z$ & 41 & 36 & 220 \\
\hline$\sim$ & $\sim$ & $\sim$ & $\sim$ & ийм сайхан; ийм том & иймм $Z$ & 46 & 41 & 197 \\
\hline$\sim$ & $\sim$ & $\sim$ & $\sim$ & $\begin{array}{l}\text { их амар; их жанжин; } \\
\text { их сургууль; их баяр; } и x \\
\text { хэрэг }\end{array}$ & ux Z & 94 & 83 & 90 \\
\hline$\sim$ & $\sim$ & $\sim$ & $\sim$ & $\begin{array}{l}\text { манай багм; манай } \\
\text { хоёр; манай муу }\end{array}$ & манай $Z$ & 42 & 37 & 216 \\
\hline$\sim$ & $\sim$ & $\sim$ & $\sim$ & маш сайн; маш сайхан & маш $Z$ & 29 & 26 & 311 \\
\hline$\sim$ & $\sim$ & $\sim$ & $\sim$ & $\begin{array}{l}\text { миний хүY; миний бие; } \\
\text { миний дүY; миний } \\
\text { нутаг; миний нэр; } \\
\text { миний охин; миний аав; } \\
\text { миний өвгөн; миний } \\
\text { хоёр; миний муу; миний } \\
\text { ард; миний сэтгэл }\end{array}$ & миний $Z$ & 336 & 297 & 25 \\
\hline
\end{tabular}


Oriental Studies. 2019. Is. 5

\begin{tabular}{|c|c|c|c|c|c|c|c|c|}
\hline$\sim$ & $\sim$ & $\sim$ & $\sim$ & $\begin{array}{l}\text { нөгөө хоёр; нөгөө хүн; } \\
\text { нөгөө муу }\end{array}$ & нөгөө $Z$ & 69 & 61 & 127 \\
\hline$\sim$ & $\sim$ & $\sim$ & $\sim$ & $\begin{array}{l}\text { нэг өдөр; нэг хэсэг; нэг } \\
\text { хүн; нэг уе; нэг том; нэг } \\
\text { муу; нэг хоёр; нэг залуу; } \\
\text { нэг сайн; нэг зэрэг; нэг } \\
\text { газар; нэг сайхан; нэг } \\
\text { шөнө; нэг эр; нэг хүүхэд }\end{array}$ & нэг $Z$ & 699 & 615 & 7 \\
\hline$\sim$ & $\sim$ & $\sim$ & $\sim$ & нэг хэсэг нь & нэг $Z$ нь & 10 & 9 & 851 \\
\hline$\sim$ & $\sim$ & $\sim$ & $\sim$ & $\begin{array}{lr}\text { нэгэн өдөр; нэгэн зэрэг; } \\
\text { нэгэн } \quad \text { хэсэг; } \\
\text { сайхан; нээгэн } \\
\text { нэгэн тогон } \\
\end{array}$ & нэгэн $Z$ & 165 & 145 & 52 \\
\hline$\sim$ & $\sim$ & $\sim$ & $\sim$ & $\begin{array}{l}\text { олон жил; олон хүн; } \\
\text { олон хоног; олон дахин; } \\
\text { олон сайхан }\end{array}$ & олон $Z$ & 168 & 149 & 51 \\
\hline$\sim$ & $\sim$ & $\sim$ & $\sim$ & пэр эр & $m Z$ эр & 15 & 13 & 551 \\
\hline$\sim$ & $\sim$ & $\sim$ & $\sim$ & ma хоёр & $\operatorname{ma} Z$ & 80 & 70 & 107 \\
\hline$\sim$ & $\sim$ & $\sim$ & $\sim$ & тас няс; тас харанхуй & $\operatorname{mac} Z$ & 60 & 53 & 141 \\
\hline$\sim$ & $\sim$ & $\sim$ & $\sim$ & $\begin{array}{l}\text { тийм том; тийм } \\
\text { сайхан; тийм хүн }\end{array}$ & muйм $Z$ & 45 & 40 & 203 \\
\hline$\sim$ & $\sim$ & $\sim$ & $\sim$ & тун сайн; тун сайхан & тун $Z$ & 32 & 28 & 288 \\
\hline$\sim$ & $\sim$ & $\sim$ & $\sim$ & $\begin{array}{l}\text { тэр хоёр; тэр хүн; тэр } \\
\text { шөнө; тэр өдөр; тэр } \\
\text { зуг; тэр сайхан; тэр } \\
\text { жил; тэр том; тэр } \\
\text { завсар; тэр муу; тэр } \\
\text { залуу; тэр даруй; тэр } \\
\text { зун; тэр зуур; тэр ойн; } \\
\text { мэр намар }\end{array}$ & mэp $Z$ & 637 & 561 & 9 \\
\hline$\sim$ & $\sim$ & $\sim$ & $\sim$ & хамаг бие; хамаг хэрэг & xamaz $Z$ & 32 & 28 & 289 \\
\hline$\sim$ & $\sim$ & $\sim$ & $\sim$ & хамаг бие нь & хамаг $Z$ нь & 26 & 23 & 334 \\
\hline$\sim$ & $\sim$ & $\sim$ & $\sim$ & хамгийн гол нь & $\begin{array}{ll}\text { хамгийн } \\
\text { нв }\end{array}$ & 15 & 13 & 552 \\
\hline$\sim$ & $\sim$ & $\sim$ & $\sim$ & хамгийн сайхан & хамгийн $Z$ & 11 & 10 & 772 \\
\hline$\sim$ & $\sim$ & $\sim$ & $\sim$ & хэд дахин; хэд хоног & хэд $Z$ & 108 & 95 & 81 \\
\hline$\sim$ & $\sim$ & $\sim$ & $\sim$ & 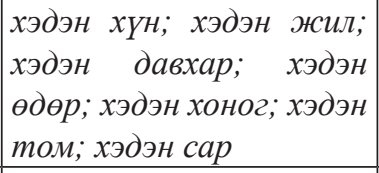 & хэдэн $Z$ & 186 & 162 & 47 \\
\hline$\sim$ & $\sim$ & $\sim$ & $\sim$ & чи ер нь & чи $Z$ нь & 16 & 14 & 510 \\
\hline$\sim$ & $\sim$ & $\sim$ & $\sim$ & чи муу & чи $Z$ & 13 & 11 & 649 \\
\hline$\sim$ & $\sim$ & $\sim$ & $\sim$ & чи бид хоёр & чи бид $Z$ & 48 & 42 & 185 \\
\hline$\sim$ & $\sim$ & $\sim$ & $\sim$ & эд хөрөнгө & эд $Z$ & 14 & 12 & 589 \\
\hline$\sim$ & $\sim$ & $\sim$ & $\sim$ & $\begin{array}{l}\text { энэ хоёр; энэ хүн; энэ } \\
\text { зуур; энэ муу; энэ жсил; } \\
\text { энэ даруй; энэ сайхан; } \\
\text { энэ өдөр; энэ шөнө; } \\
\text { энэ газар; энэ дэлхийн; } \\
\text { энэ явдал; энэ лав; энэ } \\
\text { ХҮҮхэн; энэ муусайн; } \\
\text { энэ том; энэ хҮY; энэ } \\
\text { завсар; энэ өвгөн; энэ } \\
\text { хэрэг }\end{array}$ & энэ $Z$ & 653 & 577 & 8 \\
\hline
\end{tabular}




\begin{tabular}{|c|c|c|c|c|c|c|c|c|}
\hline$\sim$ & $\sim$ & $\sim$ & $\sim$ & энэ хүн бол & энэ $Z$ бол & 11 & 10 & 773 \\
\hline$\sim$ & $\sim$ & $\sim$ & $\sim$ & энэ хорвоо дээр & энэ $Z$ дээр & 10 & 9 & 852 \\
\hline$\sim$ & $\sim$ & $\sim$ & $\sim$ & ямар сайхан; ямар хүн & я.мар $Z$ & 36 & 32 & 255 \\
\hline NOM? & 14 & 12 & 156 & чогжмаа гуай & $Z$ zуай & 14 & 12 & 584 \\
\hline PC.ACT-NOM & 67 & 59 & 63 & гэгч $\mathrm{Hb}$ & $Z \boldsymbol{H b}$ & 52 & 46 & 171 \\
\hline$\sim$ & $\sim$ & $\sim$ & $\sim$ & $2 э 248 э$ & $Z$ вэ & 15 & 13 & 553 \\
\hline $\begin{array}{l}\text { PC.DMIN-POSS. } \\
\text { REFL }\end{array}$ & 24 & 21 & 122 & нэг мэдэхнээ & нэг $Z$ & 24 & 21 & 365 \\
\hline $\begin{array}{l}\text { PC.DUR-CAR- } \\
\text { NOM }\end{array}$ & 34 & 30 & 97 & Үзээгүй тул & $Z$ тул & 17 & 15 & 488 \\
\hline$\sim$ & $\sim$ & $\sim$ & $\sim$ & болоогүй юм ииг & Z юм шиг & 17 & 15 & 489 \\
\hline $\begin{array}{l}\text { PC.DUR-GEN/ } \\
\text { ACC }\end{array}$ & 16 & 14 & 146 & байгаагий нь & $Z$ нь & 16 & 14 & 511 \\
\hline $\begin{array}{l}\text { PC.DUR-GEN- } \\
\text { NOM }\end{array}$ & 11 & 10 & 195 & байгаагийн хувьд & $Z$ хувьд & 11 & 10 & 774 \\
\hline PC.DUR-NOM & 52 & 46 & 76 & эгээ л & $Z_{\pi}$ & 28 & 25 & 320 \\
\hline $\begin{array}{l}\text { PC.DUR-NOM \& } \\
\text { VF.IND.PROF- } \\
\text { EMPH }\end{array}$ & 22 & 19 & 130 & гэж асуулаа & гэю $Z$ & 22 & 19 & 386 \\
\hline PC.DUR-NOM & 52 & 46 & 76 & гэж яваа & гэю⿻ $Z$ & 22 & 19 & 387 \\
\hline$\sim$ & $\sim$ & $\sim$ & $\sim$ & яагаа ч үгүй & $Z$ ч үгуй & 19 & 17 & 441 \\
\hline$\sim$ & $\sim$ & $\sim$ & $\sim$ & яагаа вэ & $Z$ вэ & 11 & 10 & 775 \\
\hline $\begin{array}{l}\text { PC.MERIT1-CAR- } \\
\text { NOM }\end{array}$ & 27 & 24 & 113 & тэгэлгүй яахав & $Z$ яахав & 27 & 24 & 330 \\
\hline PC.PRF-ABL & 49 & 43 & 79 & $\begin{array}{l}\text { болсноос хойш; ирснээс } \\
\text { хойш; явснаас хойш }\end{array}$ & $Z$ хойш & 49 & 43 & 180 \\
\hline PC.PRF-DAT & 14 & 12 & 157 & гэж асуусанд & 2эю⿻ $Z$ & 14 & 12 & 590 \\
\hline $\begin{array}{l}\text { PC.PRF-GEN- } \\
\text { NOM }\end{array}$ & 63 & 56 & 68 & $\begin{array}{l}\text { явсны дараа; болсны } \\
\text { дараа }\end{array}$ & $Z$ дараа & 38 & 34 & 241 \\
\hline$\sim$ & $\sim$ & $\sim$ & $\sim$ & байсньл нь; болсньл нь & $Z$ нь & 25 & 22 & 346 \\
\hline PC.PRF-NOM & 825 & 726 & 10 & $\begin{array}{l}\text { гэж бодсон; } 2 э \oiiint \\
\text { хэлсэн; гэж алдаршсан; } \\
\text { гэж ирсэн }\end{array}$ & гэж $Z$ & 121 & 106 & 73 \\
\hline$\sim$ & $\sim$ & $\sim$ & $\sim$ & $\begin{array}{l}\text { гэсэн юм; мэдсэн юм; } \\
\text { орхисон юм }\end{array}$ & $Z$ юм & 113 & 100 & 79 \\
\hline$\sim$ & $\sim$ & $\sim$ & $\sim$ & $\begin{array}{l}\text { ХэлҮҮлсэн нь; бичсэн нь; } \\
\text { гэсэн нь; тавьсан нb; } \\
\text { ярьсан нь; өмссөн нь }\end{array}$ & $Z \boldsymbol{H b}$ & 98 & 87 & 87 \\
\hline$\sim$ & $\sim$ & $\sim$ & $\sim$ & гэсэн ииц & $Z$ шиг & 90 & 79 & 93 \\
\hline$\sim$ & $\sim$ & $\sim$ & $\sim$ & гэсэн ч; яасан ч & $Z$ ч & 70 & 61 & 122 \\
\hline$\sim$ & $\sim$ & $\sim$ & $\sim$ & гэсэн чинь; тэгсэн чинь & $Z$ чинь & 61 & 54 & 137 \\
\hline$\sim$ & $\sim$ & $\sim$ & $\sim$ & $\begin{array}{l}\text { гэсэн боловч; оролдсон } \\
\text { боловч }\end{array}$ & $Z$ боловч & 57 & 50 & 148 \\
\hline$\sim$ & $\sim$ & $\sim$ & $\sim$ & $\begin{array}{l}\text { гэсэн юм ииг; болчихсон } \\
\text { юм ииг; мэдсэн юм ииц }\end{array}$ & Z юм шиг & 51 & 45 & 174 \\
\hline$\sim$ & $\sim$ & $\sim$ & $\sim$ & гэсэн мэт & $Z_{\text {мэт }}$ & 40 & 35 & 229 \\
\hline$\sim$ & $\sim$ & $\sim$ & $\sim$ & удсан ч үгүй & $Z$ ч үгүй & 31 & 27 & 295 \\
\hline$\sim$ & $\sim$ & $\sim$ & $\sim$ & мэдсэн бол; тэгсэн бол & $Z$ бол & 29 & 25 & 312 \\
\hline$\sim$ & $\sim$ & $\sim$ & $\sim$ & гэж бодсон юм & гэю $Z$ юм & 19 & 17 & 442 \\
\hline$\sim$ & $\sim$ & $\sim$ & $\sim$ & чи яасан & чи $Z$ & 14 & 12 & 591 \\
\hline$\sim$ & $\sim$ & $\sim$ & $\sim$ & гэсэн билээ & $Z$ билээ & 11 & 10 & 776 \\
\hline$\sim$ & $\sim$ & $\sim$ & $\sim$ & гэсэн юм бэ & $Z$ юм бэ & 10 & 9 & 853 \\
\hline$\sim$ & $\sim$ & $\sim$ & $\sim$ & нэг харсан чинь & нэг $Z$ чинь & 10 & 9 & 854 \\
\hline
\end{tabular}


Oriental Studies. 2019. Is. 5

\begin{tabular}{|c|c|c|c|c|c|c|c|c|}
\hline $\begin{array}{l}\text { PC.PRF-POSS. } \\
\text { REFL }\end{array}$ & 31 & 27 & 104 & гэж бодсоноо & гэю $Z$ & 31 & 27 & 296 \\
\hline PC.PROSP-ABL & 80 & 71 & 57 & гэж бодохоос & гэю⿻ $Z$ & 51 & 45 & 175 \\
\hline$\sim$ & $\sim$ & $\sim$ & $\sim$ & болохоос бим & Z биш & 29 & 26 & 313 \\
\hline PC.PROSP-ACC & 19 & 17 & 137 & байхыг хараад & $Z$ xараад & 19 & 17 & 443 \\
\hline PC.PROSP-ABL & 80 & 71 & 57 & болохоос гадна & $Z$ гадна & 11 & 10 & 777 \\
\hline PC.PROSP-ACC & 19 & 17 & 137 & байхыг үзээд & $Z_{\text {Узээд }}$ & 11 & 10 & 778 \\
\hline $\begin{array}{l}\text { PC.PROSP-CAR- } \\
\text { NOM }\end{array}$ & 48 & 43 & 81 & $\begin{array}{l}\text { авахгүй бол; тэгэхгуй } \\
\text { бол; өгөхгүй бол }\end{array}$ & $Z$ бол & 38 & 34 & 242 \\
\hline$\sim$ & $\sim$ & $\sim$ & $\sim$ & бимэдэхгүй & би $Z$ & 10 & 9 & 855 \\
\hline PC.PROSP-DAT & 639 & 563 & 16 & 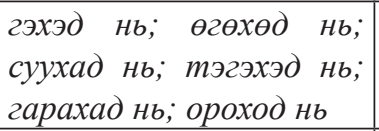 & $Z$ Hb & 376 & 331 & 22 \\
\hline$\sim$ & $\sim$ & $\sim$ & $\sim$ & $\begin{array}{l}\text { гэж бодоход; гэж } \\
\text { асуухад; гэж хэлэхэд }\end{array}$ & 2эж $Z$ & 133 & 117 & 67 \\
\hline$\sim$ & $\sim$ & $\sim$ & $\sim$ & $\begin{array}{l}\text { нэг мээдэхэд; } ; \text { нэг } \\
\text { харахад; нэг бодоход }\end{array}$ & нэг $Z$ & 130 & 115 & 68 \\
\hline $\begin{array}{l}\text { PC.PROSP-DAT- } \\
\text { POSS.REFL } \\
\end{array}$ & 34 & 30 & 98 & гэж бодохдоо & гэю⿻ $Z$ & 19 & 17 & 444 \\
\hline$\sim$ & $\sim$ & $\sim$ & $\sim$ & гэхдээ л & $Z_{\pi}$ & 15 & 13 & 554 \\
\hline PC.PROSP-DAT & 639 & 563 & 16 & миний бодоход & миний $Z$ & 14 & 12 & 592 \\
\hline$\sim$ & $\sim$ & $\sim$ & $\sim$ & энд намайг ирэхэд & \begin{tabular}{|ll} 
энд намайг \\
$Z$
\end{tabular} & 13 & 11 & 650 \\
\hline$\sim$ & $\sim$ & $\sim$ & $\sim$ & гэж хэлэхэд нь & гэж⿻ $Z$ нь & 11 & 10 & 779 \\
\hline$\sim$ & $\sim$ & $\sim$ & $\sim$ & би тэгэхэд & би $Z$ & 10 & 9 & 856 \\
\hline PC.PROSP-INSTR & 49 & 42 & 80 & $\begin{array}{l}\text { тэгэхээр нь; гэхээр нb; } \\
\text { байхаар нь }\end{array}$ & $Z$ нь & 49 & 42 & 181 \\
\hline PC.PROSP-NOM & 745 & 656 & 14 & $\begin{array}{l}\text { гэх нь; иаадах нь; ихэнх } \\
\text { нь; өгҮҮлэх нь; Үзэгдэх } \\
\text { нь; Үзэх нь; Үхэх нь; суух } \\
\text { нb; тавих нь; харагдах } \\
\text { нь; ярилцах нь }\end{array}$ & $Z$ нь & 218 & 192 & 36 \\
\hline$\sim$ & $\sim$ & $\sim$ & $\sim$ & гэх вэ; яах вэ; таарах вэ & $Z$ вэ & 98 & 87 & 88 \\
\hline$\sim$ & $\sim$ & $\sim$ & $\sim$ & $\begin{array}{l}\text { гэж хэлэх; гэж бодох; } \\
\text { гэж хашгирах }\end{array}$ & гэюж $Z$ & 65 & 57 & 132 \\
\hline$\sim$ & $\sim$ & $\sim$ & $\sim$ & $\begin{array}{l}\text { наадах чинь; изаадах } \\
\text { чинь }\end{array}$ & Zиннь & 57 & 50 & 149 \\
\hline$\sim$ & $\sim$ & $\sim$ & $\sim$ & $\begin{array}{l}\text { идэх юм; гэх } ю \text { юм; } \\
\text { санагдах юм }\end{array}$ & $Z$ юм & 56 & 49 & 154 \\
\hline$\sim$ & $\sim$ & $\sim$ & $\sim$ & гэx шиц & $Z$ шиг & 51 & 45 & 176 \\
\hline$\sim$ & $\sim$ & $\sim$ & $\sim$ & $\begin{array}{l}\text { гэх мэт; инээмсэглэх } \\
\text { мэт }\end{array}$ & $Z$ мээm & 45 & 40 & 204 \\
\hline$\sim$ & $\sim$ & $\sim$ & $\sim$ & mэгэх $Y Y ;$ гэх $Y Y$ & $Z_{Y Y}$ & 27 & 23 & 331 \\
\hline$\sim$ & $\sim$ & $\sim$ & $\sim$ & таних уу; барах уу & $Z y y$ & 22 & 20 & 388 \\
\hline$\sim$ & $\sim$ & $\sim$ & $\sim$ & гэх юм уу & $Z$ юм уу & 19 & 17 & 445 \\
\hline$\sim$ & $\sim$ & $\sim$ & $\sim$ & чадах билээ & $Z$ билээ & 15 & 13 & 555 \\
\hline$\sim$ & $\sim$ & $\sim$ & $\sim$ & гэх бол & $Z$ бол & 13 & 11 & 651 \\
\hline$\sim$ & $\sim$ & $\sim$ & $\sim$ & гэх боловч & $Z$ боловч & 13 & 11 & 652 \\
\hline$\sim$ & $\sim$ & $\sim$ & $\sim$ & Хэн мэдэх вэ & хэн $Z$ вэ & 13 & 11 & 653 \\
\hline$\sim$ & $\sim$ & $\sim$ & $\sim$ & барах уy даa & Z уудаа & 12 & 11 & 705 \\
\hline$\sim$ & $\sim$ & $\sim$ & $\sim$ & Үзэгдэх бөгөөд & $Z$ бөгөөд & 11 & 10 & 780 \\
\hline$\sim$ & $\sim$ & $\sim$ & $\sim$ & гэх вэ дээ & $Z$ вэ дээ & 10 & 9 & 857 \\
\hline $\begin{array}{l}\text { PC.PROSP-POSS. } \\
\text { REFL }\end{array}$ & 11 & 10 & 198 & байхаа даа & $Z \partial a a$ & 11 & 10 & 781 \\
\hline
\end{tabular}




\begin{tabular}{|c|c|c|c|c|c|c|c|c|}
\hline $\begin{array}{l}\text { PC.PROSP- } \\
\text { QUEST(S) } \\
\end{array}$ & 48 & 42 & 83 & байхав дээ; яахав дээ & $Z$ дээ & 37 & 32 & 246 \\
\hline$\sim$ & $\sim$ & $\sim$ & $\sim$ & тэр яахав & $m э p Z$ & 11 & 10 & 782 \\
\hline PC.US-CAR-NOM & 17 & 15 & 144 & байдаггүй юм & $Z$ юм & 17 & 15 & 490 \\
\hline PC.US-NOM & 623 & 549 & 17 & $\begin{array}{l}\text { гэдэг юм; яадаг юм; } \\
\text { ирдэг юм; санагддаг } \\
\text { юм; авдаг юм; суудаг } \\
\text { юм; ургадаг юм; хийдэг } \\
\text { юм }\end{array}$ & Z юм & 144 & 128 & 61 \\
\hline$\sim$ & $\sim$ & $\sim$ & $\sim$ & гэдэг чинь & $Z$ чинь & 139 & 122 & 64 \\
\hline$\sim$ & $\sim$ & $\sim$ & $\sim$ & гэдээ нь & $Z$ нь & 108 & 95 & 82 \\
\hline$\sim$ & $\sim$ & $\sim$ & $\sim$ & $\begin{array}{l}\text { гэж боддог; гэж Үздэг; } \\
\text { гэж нэрлэдэг }\end{array}$ & гэж $Z$ & 57 & 50 & 150 \\
\hline$\sim$ & $\sim$ & $\sim$ & $\sim$ & гэдэг бол & $Z$ бол & 52 & 46 & 172 \\
\hline$\sim$ & $\sim$ & $\sim$ & $\sim$ & яадаг билээ & $Z$ билээ & 32 & 28 & 290 \\
\hline$\sim$ & $\sim$ & $\sim$ & $\sim$ & гэдэг иүY & $Z \boldsymbol{u}_{Y Y}$ & 31 & 27 & 297 \\
\hline$\sim$ & $\sim$ & $\sim$ & $\sim$ & яадаг юм бэ & $Z$ юм бэ & 24 & 21 & 366 \\
\hline$\sim$ & $\sim$ & $\sim$ & $\sim$ & гэдэг ч & $Z u$ & 14 & 12 & 593 \\
\hline$\sim$ & $\sim$ & $\sim$ & $\sim$ & гэдэг л & $Z_{\boldsymbol{n}}$ & 12 & 11 & 706 \\
\hline$\sim$ & $\sim$ & $\sim$ & $\sim$ & гэдэг дээр & $Z$ дээр & 10 & 9 & 858 \\
\hline PL3-ACC & 11 & 10 & 199 & морьдысг нь & $Z$ нь & 11 & 10 & 783 \\
\hline PL3-NOM & 78 & 70 & 58 & эд нар; тэд нар & $Z$ нap & 34 & 30 & 273 \\
\hline$\sim$ & $\sim$ & $\sim$ & $\sim$ & тэд чинь; эд чинь & $Z$ чинь & 22 & 20 & 389 \\
\hline$\sim$ & $\sim$ & $\sim$ & $\sim$ & эд бол & $Z$ бол & 12 & 11 & 707 \\
\hline$\sim$ & $\sim$ & $\sim$ & $\sim$ & эд юм & $Z$ юм & 10 & 9 & 859 \\
\hline $\begin{array}{l}\text { PL3-REL-GEN- } \\
\text { NOM }\end{array}$ & 16 & 14 & 147 & тэдний дунд & $Z$ дуно & 16 & 14 & 512 \\
\hline $\begin{array}{l}\text { POSS.REFL \& } \\
\text { VF.IND.PROF- } \\
\text { EMPH }\end{array}$ & 66 & 58 & 65 & $\begin{array}{l}\text { гэж бодлоо; } ; \text { гэж } \\
\text { сэтгэлээ }\end{array}$ & гэж $Z$ & 66 & 58 & 130 \\
\hline POSS.REFL & 334 & 296 & 25 & 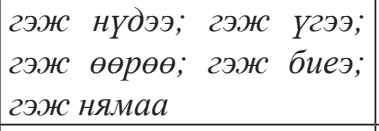 & гэж $Z$ & 61 & 54 & 138 \\
\hline$\sim$ & $\sim$ & $\sim$ & $\sim$ & би өөрөө; би чамайгаа & би $Z$ & 45 & 40 & 205 \\
\hline$\sim$ & $\sim$ & $\sim$ & $\sim$ & өөрөө ч & $Z \boldsymbol{u}$ & 40 & 35 & 230 \\
\hline$\sim$ & $\sim$ & $\sim$ & $\sim$ & гээд Үгээ; гээд нүдээ & гээд $Z$ & 30 & 27 & 303 \\
\hline$\sim$ & $\sim$ & $\sim$ & $\sim$ & тэр зуураа; тэр дороо & mэр $Z$ & 26 & 23 & 335 \\
\hline$\sim$ & $\sim$ & $\sim$ & $\sim$ & өөрөөл & $Z_{\pi}$ & 22 & 19 & 390 \\
\hline$\sim$ & $\sim$ & $\sim$ & $\sim$ & чи өөрөө & чи $Z$ & 22 & 19 & 391 \\
\hline$\sim$ & $\sim$ & $\sim$ & $\sim$ & гэмээ $\mathrm{Hb}$ & $Z$ нь & 14 & 12 & 594 \\
\hline$\sim$ & $\sim$ & $\sim$ & $\sim$ & түрҮҮлгээ харан & $Z$ харан & 12 & 11 & 708 \\
\hline$\sim$ & $\sim$ & $\sim$ & $\sim$ & сүхээ гуай & $Z$ гуай & 11 & 10 & 784 \\
\hline$\sim$ & $\sim$ & $\sim$ & $\sim$ & та өөрөө & $m a Z$ & 11 & 10 & 785 \\
\hline$\sim$ & $\sim$ & $\sim$ & $\sim$ & газраа олж & $Z$ олюс & 10 & 9 & 860 \\
\hline$\sim$ & $\sim$ & $\sim$ & $\sim$ & ганиц хүҮгээ & ганц Z & 10 & 9 & 861 \\
\hline$\sim$ & $\sim$ & $\sim$ & $\sim$ & хэдэн малаа & хэдэн $Z$ & 10 & 9 & 862 \\
\hline$\sim$ & $\sim$ & $\sim$ & $\sim$ & энэ бүхнээ & энэ $Z$ & 10 & 9 & 863 \\
\hline REL-A.COM-NOM & 15 & 13 & 153 & нэгэнт л & $Z_{\boldsymbol{n}}$ & 15 & 13 & 556 \\
\hline REL-ABL & 14 & 12 & 158 & бага наснаас & бага $Z$ & 14 & 12 & 595 \\
\hline REL-DAT & 199 & 175 & 33 & $\begin{array}{l}\text { нүдэнд нь; чихэнд нь; } \\
\text { аманд нь }\end{array}$ & $Z$ нь & 158 & 138 & 56 \\
\hline$\sim$ & $\sim$ & $\sim$ & $\sim$ & миний нүдэнд & миний $Z$ & 12 & 11 & 709 \\
\hline$\sim$ & $\sim$ & $\sim$ & $\sim$ & түҮний нүдэнд & 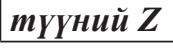 & 10 & 9 & 865 \\
\hline
\end{tabular}


Oriental Studies. 2019. Is. 5

\begin{tabular}{|c|c|c|c|c|c|c|c|c|}
\hline$\sim$ & $\sim$ & $\sim$ & $\sim$ & энэ насанд & энэ $Z$ & 19 & 17 & 446 \\
\hline $\begin{array}{l}\text { REL-DAT-POSS. } \\
\text { REFL }\end{array}$ & 45 & 40 & 87 & гэж амандаа & гэю⿻ $Z$ & 35 & 31 & 263 \\
\hline$\sim$ & $\sim$ & $\sim$ & $\sim$ & энэ насандаа & энэ $Z$ & 10 & 9 & 864 \\
\hline REL-GEN-NOM & 12 & 11 & 180 & хэн нэгний & хэн $Z$ & 12 & 11 & 710 \\
\hline REL-NOM & 774 & 682 & 13 & 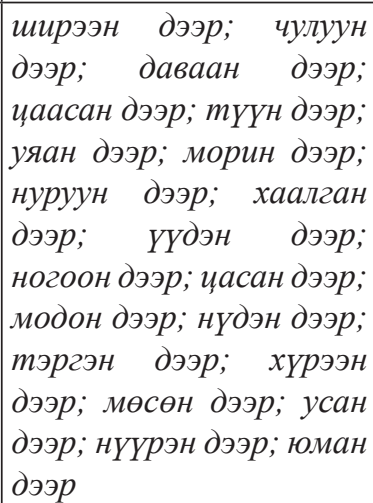 & $Z$ дээр & 365 & 320 & 24 \\
\hline$\sim$ & $\sim$ & $\sim$ & $\sim$ & $\begin{array}{l}\text { нэгэн удаa; хэдэн удаa; } \\
\text { гурван удаa }\end{array}$ & Zydaa & 62 & 55 & 135 \\
\hline$\sim$ & $\sim$ & $\sim$ & $\sim$ & $\begin{array}{l}\text { морин дээрээ; алган } \\
\text { дээрээ; дөрөөн дээрээ }\end{array}$ & $Z$ дээрээ & 39 & 34 & 235 \\
\hline$\sim$ & $\sim$ & $\sim$ & $\sim$ & $\begin{array}{l}\text { модон дотор; } у \text { усан } \\
\text { дотор }\end{array}$ & Z дотор & 22 & 20 & 392 \\
\hline$\sim$ & $\sim$ & $\sim$ & $\sim$ & нэгэн адил & $Z$ адил & 21 & 18 & 412 \\
\hline$\sim$ & $\sim$ & $\sim$ & $\sim$ & нулимс нь & $Z \mu \mathrm{Hb}$ & 16 & 14 & 513 \\
\hline$\sim$ & $\sim$ & $\sim$ & $\sim$ & аман дотроо & Z дотроо & 15 & 13 & 557 \\
\hline$\sim$ & $\sim$ & $\sim$ & $\sim$ & түYн шиг & $Z$ шиг & 14 & 12 & 596 \\
\hline$\sim$ & $\sim$ & $\sim$ & $\sim$ & $m_{Y Y^{H}}$ pYY & $Z_{p Y Y}$ & 11 & 10 & 786 \\
\hline$\sim$ & $\sim$ & $\sim$ & $\sim$ & юун ч & $Z \boldsymbol{u}$ & 11 & 10 & 787 \\
\hline$\sim$ & $\sim$ & $\sim$ & $\sim$ & нэгэн дор & $Z$ дор & 10 & 9 & 866 \\
\hline$\sim$ & $\sim$ & $\sim$ & $\sim$ & нЭг мөсөн & нэг $Z$ & 12 & 11 & 711 \\
\hline$\sim$ & $\sim$ & $\sim$ & $\sim$ & $\begin{array}{lll}\text { олон таван; олон } \\
\text { түмэн; олон зуун; олон } \\
\text { анчин }\end{array}$ & олон $Z$ & 58 & 51 & 144 \\
\hline$\sim$ & $\sim$ & $\sim$ & $\sim$ & $\begin{array}{l}\text { хэдэн зуун; хэдэн арван; } \\
\text { хэдэн мянган }\end{array}$ & хэдэн $Z$ & 89 & 79 & 96 \\
\hline$\sim$ & $\sim$ & $\sim$ & $\sim$ & хэд гурван & хэд $Z$ & 17 & 15 & 491 \\
\hline$\sim$ & $\sim$ & $\sim$ & $\sim$ & энэ гурван & энэ $Z$ & 12 & 11 & 712 \\
\hline SBJ & 1537 & 1353 & 4 & би байна & $Z$ байна & 21 & 18 & 413 \\
\hline$\sim$ & $\sim$ & $\sim$ & $\sim$ & хэн байх билээ & $Z$ байх билээ & 11 & 10 & 788 \\
\hline$\sim$ & $\sim$ & $\sim$ & $\sim$ & хэн билээ & Z билээ & 19 & 17 & 447 \\
\hline$\sim$ & $\sim$ & $\sim$ & $\sim$ & би бол; чи бол & $Z$ бол & 65 & 57 & 133 \\
\hline$\sim$ & $\sim$ & $\sim$ & $\sim$ & хэн болохыц & Z болохыг & 17 & 15 & 492 \\
\hline$\sim$ & $\sim$ & $\sim$ & $\sim$ & хэн боловч & Z боловч & 12 & 11 & 713 \\
\hline$\sim$ & $\sim$ & $\sim$ & $\sim$ & хэн бэ & $Z$ бэ & 55 & 48 & 157 \\
\hline$\sim$ & $\sim$ & $\sim$ & $\sim$ & бил; чил & $Z_{\pi}$ & 53 & 47 & 167 \\
\hline$\sim$ & $\sim$ & $\sim$ & $\sim$ & чи минь; та минь & $Z$ минь & 187 & 165 & 45 \\
\hline$\sim$ & $\sim$ & $\sim$ & $\sim$ & та нар; бид нар & $Z$ Hap & 294 & 258 & 28 \\
\hline$\sim$ & $\sim$ & $\sim$ & $\sim$ & та нарын & Z нарын & 51 & 45 & 177 \\
\hline$\sim$ & $\sim$ & $\sim$ & $\sim$ & та нар чинь & Z нар чинь & 20 & 18 & 427 \\
\hline$\sim$ & $\sim$ & $\sim$ & $\sim$ & та нар минь & $Z$ нар минь & 16 & 14 & 514 \\
\hline$\sim$ & $\sim$ & $\sim$ & $\sim$ & хэн нь & $Z$ нь & 33 & 29 & 281 \\
\hline$\sim$ & $\sim$ & $\sim$ & $\sim$ & ХЭн нь ч & $Z$ нь ч & 17 & 15 & 493 \\
\hline$\sim$ & $\sim$ & $\sim$ & $\sim$ & хэн нэг нb & $Z$ нэг нь & 18 & 16 & 465 \\
\hline
\end{tabular}




\begin{tabular}{|c|c|c|c|c|c|c|c|c|}
\hline$\sim$ & $\sim$ & $\sim$ & $\sim$ & хэн хэн нb & $Z$ хэн нь & 15 & 13 & 558 \\
\hline$\sim$ & $\sim$ & $\sim$ & $\sim$ & $\begin{array}{l}\text { бич; хэн ч; чи ч; бидч; } \\
\text { тач }\end{array}$ & $Z 4$ & 431 & 379 & 15 \\
\hline$\sim$ & $\sim$ & $\sim$ & $\sim$ & хэн ч үгуй & $Z$ ч Yгуй & 16 & 14 & 515 \\
\hline$\sim$ & $\sim$ & $\sim$ & $\sim$ & хэн ч мэдэхгүй & $Z$ ч мэдэхгүй & 14 & 12 & 597 \\
\hline$\sim$ & $\sim$ & $\sim$ & $\sim$ & $\begin{array}{l}\text { би чинь; чи чинь; бид } \\
\text { чннь; та чинь }\end{array}$ & $Z$ чинь & 172 & 152 & 49 \\
\hline VF.IND.AOR & 458 & 404 & 20 & 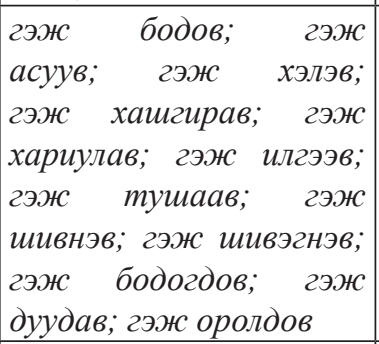 & гэж $Z$ & 417 & 368 & 17 \\
\hline$\sim$ & $\sim$ & $\sim$ & $\sim$ & мэдэв $Y Y$ & $Z_{Y Y}$ & 25 & 22 & 347 \\
\hline$\sim$ & $\sim$ & $\sim$ & $\sim$ & гээд инээмсэглэв & гээд $Z$ & 16 & 14 & 516 \\
\hline $\begin{array}{l}\text { VF.IND.AOR \& } \\
\{\text { PART }\}\end{array}$ & 12 & 11 & 181 & гэв $Y Y$ & $Z_{Y Y}$ & 12 & 11 & 714 \\
\hline VF.IND.AOR & 458 & 404 & 20 & гэхэв дээ & $Z$ дээ & 11 & 10 & 789 \\
\hline $\begin{array}{l}\text { VF.IND.PROF- } \\
\text { EMPH }\end{array}$ & 243 & 215 & 29 & гэлээ ч; яалаа ч & $Z u$ & 165 & 146 & 53 \\
\hline$\sim$ & $\sim$ & $\sim$ & $\sim$ & $\begin{array}{l}\text { гэж зүУдэллээ; } 2 \text { гэж } \\
\text { хэллээ; гэж ирлээ; гэж } \\
\text { ярилаа }\end{array}$ & гэж $Z$ & 53 & 47 & 168 \\
\hline$\sim$ & $\sim$ & $\sim$ & $\sim$ & хэн мэдлээ & $x э \boldsymbol{Z}$ & 25 & 22 & 348 \\
\hline $\begin{array}{l}\text { VF.IND.PROF(Q) } \\
\text { \& NOM }\end{array}$ & 12 & 11 & 182 & 2эл $Y Y$ & $Z_{Y Y}$ & 12 & 11 & 715 \\
\hline VF.IND.PRS1 & 404 & 356 & 22 & $\begin{array}{l}\text { гэж бодно; гэж санана; } \\
\text { гэж } \text { бодогдоно; гэж } \\
\text { явна }\end{array}$ & гэю $Z$ & 163 & 144 & 54 \\
\hline$\sim$ & $\sim$ & $\sim$ & $\sim$ & гэнэ билээ & $Z$ билээ & 66 & 58 & 131 \\
\hline$\sim$ & $\sim$ & $\sim$ & $\sim$ & гэнэ шүу; орхино шүY & $Z u_{Y Y}$ & 52 & 45 & 173 \\
\hline$\sim$ & $\sim$ & $\sim$ & $\sim$ & байна уу & Zyy & 19 & 17 & 448 \\
\hline$\sim$ & $\sim$ & $\sim$ & $\sim$ & гэнэ ээ & $Z$ ээ & 18 & 16 & 466 \\
\hline$\sim$ & $\sim$ & $\sim$ & $\sim$ & яана аа & $Z a a$ & 17 & 15 & 494 \\
\hline$\sim$ & $\sim$ & $\sim$ & $\sim$ & би мэднэ & би $Z$ & 17 & 15 & 495 \\
\hline$\sim$ & $\sim$ & $\sim$ & $\sim$ & гэнэ $Y Y$ & $Z_{Y Y}$ & 16 & 14 & 517 \\
\hline$\sim$ & $\sim$ & $\sim$ & $\sim$ & яана даа & $Z \partial a a$ & 16 & 14 & 518 \\
\hline$\sim$ & $\sim$ & $\sim$ & $\sim$ & Хэлнэ вэ & $Z$ вэ & 10 & 9 & 867 \\
\hline$\sim$ & $\sim$ & $\sim$ & $\sim$ & эс чадна & эc $Z$ & 10 & 9 & 868 \\
\hline $\begin{array}{l}\text { VF.IND.RENARR- } \\
\text { EMPH }\end{array}$ & 45 & 40 & 88 & гэж боджээ & гэю $Z$ & 33 & 29 & 282 \\
\hline$\sim$ & $\sim$ & $\sim$ & $\sim$ & энэ ажээ & энэ $Z$ & 12 & 11 & 716 \\
\hline VF.OPT.IMP & 173 & 153 & 37 & бүY мэว & $\sigma_{Y Y} Z$ & 136 & 120 & 66 \\
\hline$\sim$ & $\sim$ & $\sim$ & $\sim$ & буй заа & буй $Z$ & 37 & 33 & 247 \\
\hline $\begin{array}{l}\text { VF.OPT.IMP \& } \\
\{A D V\} \&\{A D V\}\end{array}$ & 17 & 15 & 145 & яв явсаар & $Z$ явсаар & 17 & 15 & 496 \\
\hline VF.OPT.IMP & 173 & 153 & 37 & хийл & $Z_{\pi}$ & 12 & 11 & 717 \\
\hline$\sim$ & $\sim$ & $\sim$ & $\sim$ & гэж мэд & гэж $Z$ & 12 & 11 & 718 \\
\hline VF.OPT.JUSS & 20 & 18 & 135 & хэн байг & хэн $Z$ & 20 & 18 & 428 \\
\hline VF.OPT.RECOM & 25 & 22 & 118 & $\begin{array}{l}\text { гэж хээлээрэй; } ; ~ г э ж \\
\text { мэдээрэй }\end{array}$ & гэю⿻ $Z$ & 25 & 22 & 349 \\
\hline VF.OPT.VOL & 11 & 10 & 201 & би явъя & би $Z$ & 11 & 10 & 790 \\
\hline
\end{tabular}


Oriental Studies. 2019. Is. 5

\begin{tabular}{|c|c|c|c|c|c|c|c|c|}
\hline$\{\mathrm{ADV}\}$ & 112 & 99 & 43 & ягл & $Z_{\pi}$ & 84 & 74 & 101 \\
\hline$\sim$ & $\sim$ & $\sim$ & $\sim$ & $x \ni р н ь$ & $Z$ нь & 28 & 25 & 321 \\
\hline $\begin{array}{l}\{\mathrm{ADV}\} \& \text { CVB. } \\
\text { ANT }\end{array}$ & 23 & 20 & 127 & чи яагаад & чи $Z$ & 23 & 20 & 377 \\
\hline $\begin{array}{l}\{\text { ADV }\} \& \text { CVB. } \\
\text { CNGR }\end{array}$ & 35 & 31 & 95 & яаж байна & $Z$ байна & 19 & 17 & 449 \\
\hline$\sim$ & $\sim$ & $\sim$ & $\sim$ & яаж ч & $Z u$ & 16 & 14 & 519 \\
\hline $\begin{array}{l}\{\mathrm{ADV}\} \& \text { CVB. } \\
\text { ANT }\end{array}$ & 23 & 20 & 127 & яагаад ч юм & Zч юм & 13 & 11 & 654 \\
\hline $\begin{array}{l}\{\text { ADV }\} \& \text { CVB. } \\
\text { CNGR }\end{array}$ & 35 & 31 & 95 & би яаж & би $Z$ & 13 & 11 & 655 \\
\hline$\sim$ & $\sim$ & $\sim$ & $\sim$ & чи яаж байна & чи $Z$ байна & 11 & 10 & 791 \\
\hline$\{\mathrm{ADV}\} \&$ DAT & 10 & 9 & 212 & гээ ихэд & гэभ⿻ $Z$ & 10 & 9 & 869 \\
\hline $\begin{array}{l}\{\text { ADV }\} \& \text { DAT- } \\
\text { POSS.REFL }\end{array}$ & 33 & 29 & 100 & Үнэндээ ч & $Z u$ & 21 & 18 & 414 \\
\hline$\sim$ & $\sim$ & $\sim$ & $\sim$ & Үнэндээ бол & $Z$ бол & 12 & 11 & 719 \\
\hline$\{\mathrm{ADV}\}$ & 112 & 99 & 43 & аль хэр & аль $Z$ & 15 & 13 & 559 \\
\hline$\sim$ & $\sim$ & $\sim$ & $\sim$ & энэ хэр & энэ $Z$ & 12 & 11 & 720 \\
\hline$\{A D V\} D A T$ & 86 & 76 & 53 & бусад нь & $Z \mu \mathrm{Hb}$ & 86 & 76 & 98 \\
\hline$\{$ ADV $\}$ ESS1 & 91 & 81 & 51 & хаана вэ & $Z_{63}$ & 36 & 32 & 256 \\
\hline$\sim$ & $\sim$ & $\sim$ & $\sim$ & хаана байна & $Z$ байна & 35 & 31 & 264 \\
\hline$\sim$ & $\sim$ & $\sim$ & $\sim$ & хаана байна вэ & $Z$ байна вэ & 10 & 9 & 870 \\
\hline$\sim$ & $\sim$ & $\sim$ & $\sim$ & хаана ч & $Z$ u & 10 & 9 & 871 \\
\hline $\begin{array}{l}\{\text { ADV }\} \text { LAT-POSS. } \\
\text { REFL }\end{array}$ & 19 & 17 & 138 & хаамаа ч & $Z u$ & 19 & 17 & 450 \\
\hline$\{A D V\} N O M$ & 46 & 41 & 86 & хаа байна & Z байна & 29 & 26 & 314 \\
\hline$\sim$ & $\sim$ & $\sim$ & $\sim$ & xaay & $Z u$ & 17 & 15 & 497 \\
\hline$\{$ ART $\}$ NOM & 25 & 22 & 119 & даxb $\mathrm{Hb}$ & $Z$ Hb & 25 & 22 & 350 \\
\hline$\{\mathrm{COMM}\}$ & 84 & 75 & 54 & за яахав & $Z$ яахав & 53 & 47 & 169 \\
\hline$\sim$ & $\sim$ & $\sim$ & $\sim$ & $3 a \partial a a$ & $Z$ дaa & 20 & 18 & 429 \\
\hline$\sim$ & $\sim$ & $\sim$ & $\sim$ & за яах вэ & $Z$ яах вэ & 11 & 10 & 792 \\
\hline $\begin{array}{l}\text { \{LOC }\} \text { A.ATTEN1- } \\
\text { POSS.REFL }\end{array}$ & 15 & 13 & 154 & тэр дорхноо & $m э p Z$ & 15 & 13 & 560 \\
\hline$\{\mathrm{LOC}\} \mathrm{ABL}$ & 129 & 113 & 41 & $\begin{array}{l}\text { өмнөөс нь; дороос } \mathrm{Hb} ; \\
\text { дээрээс нь }\end{array}$ & $Z$ нь & 81 & 71 & 105 \\
\hline$\sim$ & $\sim$ & $\sim$ & $\sim$ & олныл дундаас & олны $Z$ & 10 & 9 & 872 \\
\hline$\sim$ & $\sim$ & $\sim$ & $\sim$ & тэр дундаас & mэр $Z$ & 38 & 33 & 243 \\
\hline$\{$ LOC $\}$ ABS-ABL & 16 & 14 & 148 & хажуугаас нь & $Z \mu \mathrm{b}$ & 16 & 14 & 520 \\
\hline$\{$ LOC $\} D A T$ & 104 & 91 & 46 & хажууд нь; урд нь & $Z \mu \mathrm{Hb}$ & 90 & 79 & 94 \\
\hline$\sim$ & $\sim$ & $\sim$ & $\sim$ & урд тальын & $Z$ тальн & 14 & 12 & 598 \\
\hline$\{$ LOC $\} D A T-A B L$ & 12 & 11 & 183 & урдаас нь & $Z \mu \mathrm{b}$ & 12 & 11 & 721 \\
\hline $\begin{array}{l}\text { \{LOC\}DAT- } \\
\text { TRANSL }\end{array}$ & 11 & 10 & 202 & урдуур нь & $Z$ нь & 11 & 10 & 793 \\
\hline$\{$ LOC $\}$ ESS1-ABL & 51 & 45 & 77 & хойноос нь; гаднаас нь & $Z$ нь & 51 & 45 & 178 \\
\hline$\{$ LOC\}ESS1-NOM & 30 & 26 & 106 & изаана нь & $Z \mu \mathrm{b}$ & 23 & 20 & 378 \\
\hline$\{$ LOC $\}$ ESS1-ABL & 51 & 45 & 77 & түҮний хойноос & 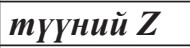 & 22 & 19 & 393 \\
\hline$\{$ LOC\}ESS1-NOM & 30 & 26 & 106 & ијаана чинь & $Z$ чинь & 15 & 13 & 561 \\
\hline$\sim$ & $\sim$ & $\sim$ & $\sim$ & түҮний хойно & түҮний $Z$ & 15 & 13 & 562 \\
\hline$\{$ LOC $\}$ ESS1-ABL & 51 & 45 & 77 & миний хойноос & миний $Z$ & 14 & 12 & 599 \\
\hline$\{$ LOC $\}$ ESS2 & 38 & 33 & 92 & дээр нь; доор нь & $Z$ Hb & 38 & 33 & 244 \\
\hline $\begin{array}{l}\text { \{LOC }\} \text { ESS2-POSS. } \\
\text { REFL }\end{array}$ & 75 & 66 & 60 & гэж дотроо & гэю⿻ $Z$ & 75 & 66 & 115 \\
\hline$\{$ LOC $\}$ ESS2-NOM & 34 & 30 & 99 & дотор нь & $Z$ нь & 34 & 30 & 274 \\
\hline
\end{tabular}




\begin{tabular}{|c|c|c|c|c|c|c|c|c|}
\hline$\{$ LOC $\}$ INSTR & 30 & 26 & 107 & хажуугаар нь & $Z$ нь & 30 & 26 & 304 \\
\hline$\{$ LOC $\}$ LAT & 215 & 190 & 32 & $\begin{array}{l}\text { य̧ааш нь; доош нь; дээщ } \\
\text { нь; нааш нь }\end{array}$ & $Z$ нь & 83 & 73 & 102 \\
\hline$\sim$ & $\sim$ & $\sim$ & $\sim$ & цуааш явлаа & $Z$ явлаа & 13 & 11 & 656 \\
\hline$\sim$ & $\sim$ & $\sim$ & $\sim$ & доошххаран & $Z$ харан & 12 & 11 & 722 \\
\hline$\sim$ & $\sim$ & $\sim$ & $\sim$ & гадагш гарч & $Z$ zapu & 10 & 9 & 873 \\
\hline$\sim$ & $\sim$ & $\sim$ & $\sim$ & гээд иџааш & гээठ $Z$ & 15 & 13 & 563 \\
\hline$\sim$ & $\sim$ & $\sim$ & $\sim$ & гээд ичааш нь & гээд $Z$ нь & 10 & 9 & 874 \\
\hline$\sim$ & $\sim$ & $\sim$ & $\sim$ & $\begin{array}{l}\text { түҮнээс хойш; түУнээс } \\
\text { цуааш }\end{array}$ & $\boldsymbol{m}_{\text {ҮҮнээс } Z}$ & 72 & 64 & 119 \\
\hline$\{L O C\} N O M$ & 105 & 92 & 45 & $\begin{array}{l}\text { дэргэд нь; хооронд нь; } \\
\text { өмнө нь }\end{array}$ & Z нь & 69 & 61 & 128 \\
\hline$\sim$ & $\sim$ & $\sim$ & $\sim$ & хажуу тийш & $Z$ тийш & 13 & 11 & 657 \\
\hline$\sim$ & $\sim$ & $\sim$ & $\sim$ & энэ хооронд & энэ $Z$ & 23 & 20 & 379 \\
\hline$\{$ LOC $\}$ POSS.REFL & 10 & 9 & 213 & мэр дундаа & mэр $Z$ & 10 & 9 & 875 \\
\hline$\{$ LOC $\}$ REL-ABL & 11 & 10 & 203 & хажуунаас нь & $Z$ нь & 11 & 10 & 794 \\
\hline$\{$ LOC $\}$ TRANSL & 25 & 22 & 120 & $\begin{array}{ll}\text { дундуур } & н b ; \\
н b\end{array}$ & $Z$ нь & 25 & 22 & 351 \\
\hline $\begin{array}{l}\{\text { PART }\} \& \text { ABS- } \\
\text { NOM }\end{array}$ & 1045 & 917 & 6 & юуч & $Z u$ & 291 & 256 & 29 \\
\hline$\sim$ & $\sim$ & $\sim$ & $\sim$ & юу вэ & $Z$ вэ & 121 & 106 & 74 \\
\hline$\sim$ & $\sim$ & $\sim$ & $\sim$ & юу билээ & $Z$ билээ & 77 & 68 & 112 \\
\hline$\sim$ & $\sim$ & $\sim$ & $\sim$ & юу байх вэ & $Z$ байх вэ & 37 & 33 & 248 \\
\hline$\sim$ & $\sim$ & $\sim$ & $\sim$ & чи юу & чи $Z$ & 37 & 33 & 249 \\
\hline$\sim$ & $\sim$ & $\sim$ & $\sim$ & юу болохьлг & Z болохыг & 36 & 32 & 257 \\
\hline$\sim$ & $\sim$ & $\sim$ & $\sim$ & юу болов & $Z$ болов & 32 & 28 & 291 \\
\hline$\sim$ & $\sim$ & $\sim$ & $\sim$ & юу даa & $Z \partial a a$ & 24 & 21 & 367 \\
\hline$\sim$ & $\sim$ & $\sim$ & $\sim$ & өөр юу ч & $\operatorname{\theta \theta p} Z$ ч & 24 & 21 & 368 \\
\hline$\sim$ & $\sim$ & $\sim$ & $\sim$ & юу ч үгүй & $Z$ ч үгүй & 23 & 20 & 380 \\
\hline$\sim$ & $\sim$ & $\sim$ & $\sim$ & юу байна & $Z$ байна & 22 & 19 & 394 \\
\hline$\sim$ & $\sim$ & $\sim$ & $\sim$ & юучл & $Z$ ил & 22 & 19 & 395 \\
\hline$\sim$ & $\sim$ & $\sim$ & $\sim$ & юу юм бэ & $Z$ юм бэ & 21 & 18 & 415 \\
\hline$\sim$ & $\sim$ & $\sim$ & $\sim$ & биюу & би $Z$ & 21 & 18 & 416 \\
\hline$\sim$ & $\sim$ & $\sim$ & $\sim$ & ma юу & $m a Z$ & 21 & 18 & 417 \\
\hline$\sim$ & $\sim$ & $\sim$ & $\sim$ & юу болж байгааг & \begin{tabular}{|l|}
$Z$ \\
байгааг \\
\end{tabular} & 20 & 18 & 430 \\
\hline$\sim$ & $\sim$ & $\sim$ & $\sim$ & юу байх билээ & $Z$ байх билээ & 17 & 15 & 498 \\
\hline$\sim$ & $\sim$ & $\sim$ & $\sim$ & юу $\mathrm{Hb}$ & $Z \mathrm{Hb}$ & 17 & 15 & 499 \\
\hline$\sim$ & $\sim$ & $\sim$ & $\sim$ & юу хийж & $Z$ хийэс & 17 & 15 & 500 \\
\hline$\sim$ & $\sim$ & $\sim$ & $\sim$ & юу бодож & $Z$ бодож & 15 & 13 & 564 \\
\hline$\sim$ & $\sim$ & $\sim$ & $\sim$ & гэж юу & гэю⿻ $Z$ & 15 & 13 & 565 \\
\hline$\sim$ & $\sim$ & $\sim$ & $\sim$ & юу болоод & $Z$ болоод & 14 & 12 & 600 \\
\hline$\sim$ & $\sim$ & $\sim$ & $\sim$ & юу ч бим & Zч бии & 14 & 12 & 601 \\
\hline$\sim$ & $\sim$ & $\sim$ & $\sim$ & юу байдаг билээ & \begin{tabular}{|l|}
$Z$ \\
билээ
\end{tabular} & 13 & 11 & 658 \\
\hline$\sim$ & $\sim$ & $\sim$ & $\sim$ & юу ч алга & $Z$ ч алга & 13 & 11 & 659 \\
\hline$\sim$ & $\sim$ & $\sim$ & $\sim$ & юу ч болсон & $Z$ ч болсон & 13 & 11 & 660 \\
\hline$\sim$ & $\sim$ & $\sim$ & $\sim$ & өөр юу & $\operatorname{\theta өp} Z$ & 13 & 11 & 661 \\
\hline$\sim$ & $\sim$ & $\sim$ & $\sim$ & юу болж & $Z$ болжс & 12 & 11 & 723 \\
\hline$\sim$ & $\sim$ & $\sim$ & $\sim$ & юу боллоо & $Z$ боллоо & 11 & 10 & 795 \\
\hline$\sim$ & $\sim$ & $\sim$ & $\sim$ & юу болох вэ & $Z$ болох вэ & 11 & 10 & 796 \\
\hline$\sim$ & $\sim$ & $\sim$ & $\sim$ & юу хийх вэ & $Z$ хийх вэ & 11 & 10 & 797 \\
\hline$\sim$ & $\sim$ & $\sim$ & $\sim$ & юул & $Z_{\pi}$ & 10 & 9 & 876 \\
\hline
\end{tabular}


Oriental Studies. 2019. Is. 5

\begin{tabular}{|c|c|c|c|c|c|c|c|c|}
\hline$\{$ PART $\}$ & 1329 & 1171 & 5 & мөн л; басл & $Z_{\pi}$ & 442 & 389 & 14 \\
\hline$\sim$ & $\sim$ & $\sim$ & $\sim$ & $\begin{array}{l}\text { мөн ч; харин ч; бас ч; } \\
\text { мун ч; маань ч }\end{array}$ & $Z u$ & 395 & 348 & 19 \\
\hline$\sim$ & $\sim$ & $\sim$ & $\sim$ & иив дээ; ээ дээ; үحүй дээ & $Z$ дээ & 140 & 123 & 63 \\
\hline$\sim$ & $\sim$ & $\sim$ & $\sim$ & үгүй ээ; харин ээ & $Z$ ээ & 120 & 105 & 77 \\
\hline$\sim$ & $\sim$ & $\sim$ & $\sim$ & эс бол; үгүй бол & $Z$ бол & 46 & 40 & 198 \\
\hline$\sim$ & $\sim$ & $\sim$ & $\sim$ & бус yy & $Z y y$ & 45 & 40 & 206 \\
\hline$\sim$ & $\sim$ & $\sim$ & $\sim$ & Үл мэднэ & 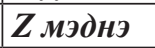 & 40 & 35 & 231 \\
\hline$\sim$ & $\sim$ & $\sim$ & $\sim$ & Үл болно & $Z$ болно & 19 & 17 & 451 \\
\hline$\sim$ & $\sim$ & $\sim$ & $\sim$ & мөн $Y Y$ & $Z_{Y Y}$ & 18 & 16 & 468 \\
\hline$\sim$ & $\sim$ & $\sim$ & $\sim$ & мөн байна & $Z$ байна & 18 & 16 & 469 \\
\hline$\sim$ & $\sim$ & $\sim$ & $\sim$ & жав гуай & $Z$ zуай & 12 & 11 & 724 \\
\hline$\sim$ & $\sim$ & $\sim$ & $\sim$ & Үл мэдэх & $Z$ мээдэx & 12 & 11 & 725 \\
\hline$\sim$ & $\sim$ & $\sim$ & $\sim$ & үгүй шүY & $Z u_{Y Y}$ & 12 & 11 & 726 \\
\hline$\sim$ & $\sim$ & $\sim$ & $\sim$ & бас бий & $Z$ бий & 10 & 9 & 877 \\
\hline $\begin{array}{l}\{\text { PART }\} \& \text { CVB. } \\
\text { MOD }\end{array}$ & 18 & 16 & 142 & даан ч & $Z u$ & 18 & 16 & 467 \\
\hline$\{$ PART $\}$ & 1329 & 1171 & 5 & гэдэг маань & гэдэг $Z$ & 26 & 23 & 336 \\
\hline$\sim$ & $\sim$ & $\sim$ & $\sim$ & гэж үгүй & гэभ⿻ $Z$ & 10 & 9 & 878 \\
\hline$\sim$ & $\sim$ & $\sim$ & $\sim$ & гэж мөн & гэюс $Z$ л & 10 & 9 & 879 \\
\hline$\sim$ & $\sim$ & $\sim$ & $\sim$ & гэх буюу & $29 x Z$ & 10 & 9 & 880 \\
\hline$\sim$ & $\sim$ & $\sim$ & $\sim$ & тэр маань & mэр $Z$ & 16 & 14 & 521 \\
\hline$\sim$ & $\sim$ & $\sim$ & $\sim$ & энэ маань & энэ $Z$ & 21 & 18 & 418 \\
\hline$\{$ PART $\}$ ABL & 57 & 50 & 71 & энэ учраас & энэ $Z$ & 57 & 50 & 151 \\
\hline $\begin{array}{l}\text { \{PART\}CVB. } \\
\text { COND1 }\end{array}$ & 32 & 28 & 102 & аль эсвэл & аль $Z$ & 32 & 28 & 292 \\
\hline $\begin{array}{l}\text { \{PART }\} \text { EMPH \& } \\
\text { POSS.REFL } \\
\end{array}$ & 12 & 11 & 184 & хамаг юмаа & хамаг $Z$ & 12 & 11 & 727 \\
\hline$\{$ PART\}NOM & 63 & 55 & 69 & учир нь & $Z$ нь & 63 & 55 & 134 \\
\hline \{POST.REL\}DAT & 19 & 17 & 139 & энэ тухайд & энэ $Z$ & 19 & 17 & 452 \\
\hline$\{$ POST.REL\}NOM & 11 & 10 & 204 & миний төлөө & миний $Z$ & 11 & 10 & 798 \\
\hline$\{$ POST.REL\}DAT & 19 & 17 & 139 & тухайд бол & $Z$ бол & 10 & 9 & 881 \\
\hline$\{$ TEMP $\}$ & 29 & 26 & 108 & дандаал & $Z \pi$ & 18 & 16 & 470 \\
\hline$\sim$ & $\sim$ & $\sim$ & $\sim$ & хожим нь & $Z$ Hb & 11 & 10 & 799 \\
\hline $\begin{array}{l}\text { \{TEMP }\} \\
\text { A.ATTEN1-NOM }\end{array}$ & 25 & 22 & 121 & гэж аяархан & гэж $Z$ & 15 & 13 & 566 \\
\hline$\sim$ & $\sim$ & $\sim$ & $\sim$ & би одоохон & би $Z$ & 10 & 9 & 882 \\
\hline$\{$ TEMP $\}$ ABS-NOM & 28 & 25 & 112 & сая л & $Z_{\boldsymbol{n}}$ & 28 & 25 & 322 \\
\hline$\{$ TEMP $\}$ DAT & 14 & 12 & 160 & дараад нь & $Z \mathrm{Hb}$ & 14 & 12 & 602 \\
\hline $\begin{array}{l}\{\text { TEMP }\} \text { DMIN- } \\
\text { NOM }\end{array}$ & $\sim$ & $\sim$ & 161 & тун саяхан & тун $Z$ & 14 & 12 & 603 \\
\hline$\{$ TEMP\}GEN-NOM & 35 & 31 & 96 & оройн нар & $Z$ uap & 25 & 22 & 352 \\
\hline$\sim$ & $\sim$ & $\sim$ & $\sim$ & урьдылн адил & Zадил & 10 & 9 & 883 \\
\hline$\{$ TEMP $\}$ NOM & 948 & 833 & 8 & $\begin{array}{l}\text { дараа нь; маргааш нь; } \\
\text { орой нь; урьд нь }\end{array}$ & $Z$ нь & 391 & 343 & 20 \\
\hline$\sim$ & $\sim$ & $\sim$ & $\sim$ & Хэзээ ч; одоо ч & $Z u$ & 216 & 190 & 38 \\
\hline$\sim$ & $\sim$ & $\sim$ & $\sim$ & $\begin{array}{l}\text { гэтэл } \quad \text { одоо; гэтэл } \\
\text { гэнэт; гэтэл өнөөдөр }\end{array}$ & гэтэл $Z$ & 54 & 48 & 164 \\
\hline$\sim$ & $\sim$ & $\sim$ & $\sim$ & одоол & $Z_{\pi}$ & 47 & 41 & 191 \\
\hline$\sim$ & $\sim$ & $\sim$ & $\sim$ & би одоо; би өнөөдөр & би $Z$ & 42 & 37 & 217 \\
\hline$\sim$ & $\sim$ & $\sim$ & $\sim$ & урьд өмнө & $Z$ өмнө & 39 & 34 & 236 \\
\hline$\sim$ & $\sim$ & $\sim$ & $\sim$ & тэр орой & mэр $Z$ & 39 & 34 & 237 \\
\hline$\sim$ & $\sim$ & $\sim$ & $\sim$ & гэж гэнэт; гэж үргэлж & гээж $Z$ & 33 & 29 & 283 \\
\hline
\end{tabular}




\begin{tabular}{|c|c|c|c|c|c|c|c|c|}
\hline$\sim$ & $\sim$ & $\sim$ & $\sim$ & одоо хүртэл & Zхуртээл & 30 & 26 & 305 \\
\hline$\sim$ & $\sim$ & $\sim$ & $\sim$ & одоо бол & $Z$ бол & 29 & 26 & 315 \\
\hline$\sim$ & $\sim$ & $\sim$ & $\sim$ & орой дээр & $Z$ дээр & 28 & 25 & 323 \\
\hline $\begin{array}{l}\{\text { TEMP }\} \text { NOM } \\
\& \text { ABS-NOM \& } \\
\text { A.COM-NOM \& } \\
\text { DAT }\end{array}$ & 23 & 20 & 129 & аль эрт & аль $Z$ & 23 & 20 & 381 \\
\hline$\{$ TEMP\}NOM & 948 & 833 & 8 & чи одоо & чи $Z$ & 22 & 19 & 396 \\
\hline$\sim$ & $\sim$ & $\sim$ & $\sim$ & нэг орой & нэг $Z$ & 21 & 18 & 419 \\
\hline$\sim$ & $\sim$ & $\sim$ & $\sim$ & гэв гэнэт & $296 Z$ & 20 & 18 & 431 \\
\hline$\sim$ & $\sim$ & $\sim$ & $\sim$ & та одоо & $m a Z$ & 19 & 17 & 453 \\
\hline$\sim$ & $\sim$ & $\sim$ & $\sim$ & харин одоо & харин $Z$ & 17 & 15 & 501 \\
\hline$\sim$ & $\sim$ & $\sim$ & $\sim$ & орой дээрээ & $Z$ дээрээ & 15 & 13 & 567 \\
\hline $\begin{array}{l}\{\text { TEMP }\} \text { NOM \& } \\
\text { GEN-NOM }\end{array}$ & 14 & 12 & 162 & өнөөдрийн хувьд & $Z$ хувьд & 14 & 12 & 604 \\
\hline$\{$ TEMP\}NOM & 948 & 833 & 8 & энэ орой & энэ $Z$ & 13 & 11 & 662 \\
\hline$\sim$ & $\sim$ & $\sim$ & $\sim$ & орой нар & Z нар & 12 & 11 & 728 \\
\hline$\sim$ & $\sim$ & $\sim$ & $\sim$ & одоо яах вэ & $Z$ яах вэ & 12 & 11 & 729 \\
\hline$\sim$ & $\sim$ & $\sim$ & $\sim$ & маргааш явлаа & $Z$ явлаа & 11 & 10 & 800 \\
\hline$\sim$ & $\sim$ & $\sim$ & $\sim$ & орой болж & $Z$ болюс & 10 & 9 & 884 \\
\hline$\sim$ & $\sim$ & $\sim$ & $\sim$ & одоо болохоор & $Z$ болохоор & 10 & 9 & 885 \\
\hline $\begin{array}{l}\text { \{TEMP }\} \text { POSS. } \\
\text { REFL }\end{array}$ & 16 & 14 & 149 & тэр аяараа & mэр $Z$ & 16 & 14 & 522 \\
\hline $\mathbf{0}$ & 20 & 18 & 134 & гэнЭ ЛЭэ & 2энэ $Z$ & 20 & 18 & 420 \\
\hline$?$ & 37 & 32 & 93 & бил $Y Y$ & $Z_{Y Y}$ & 24 & 21 & 353 \\
\hline$\sim$ & $\sim$ & $\sim$ & $\sim$ & би вээр & би $Z$ & 13 & 11 & 605 \\
\hline
\end{tabular}

Заключение

Дистрибутивно-вероятностный подход к выделению типов монгольских аналитических конструкций открывает путь к изучению грамматического (в особенности, так называемого «морфосинтаксического») строя монгольского языка, ибо конкретные вхождения абстрактных АК и их компонентов в Генеральный корпус монгольского языка, встречаемость которых подвергается квантитативному измерению, соотнесены с морфолого-синтаксическими единицами самого монгольского языка. Статистический подход даёт возможность описывать квантитативные особенности различных АК в письменных текстах ${ }^{4}$. В ходе такого описания аккумулируются обобщённые количественные сведения о типах АК, об употребительности разных АК в тех или иных ролях и контекстах и т. п. Такие дан-

\footnotetext{
${ }^{4}$ См.: [Шайкевич 1990; Шайкевич 2009].
}

ные углубляют эмпирическую базу теории АК монгольского языка. В результате возникает надежда на то, что традиционная структурная модель монгольской грамматики ${ }^{5}$ постепенно трансформируется в структурно-вероятностную модель монгольской грамматики ${ }^{6}$, в которой учитываются результаты статистического анализа текстов. Распространение дистрибутивно-статистического подхода на сферу аналитизма позволяет представить все АК монгольского языка как обладающие определённым количественным «весом»; измеряемыми оказываются также их языковые противопоставления и связи.

${ }^{5}$ См., напр.: [Крылов 2004] и указанную там литературу.

6 Для синтетических словоформ такая модель была построена в [Крылов 2014] и указанных там статьях 2012-2013 гг. 


\section{Литература}

Виноградов 1947 - Виноградов В. В. Русский язык (Грамматическое учение о слове) Учеб. пособие для вузов. М.; Л.: Учпедгиз, $1947.784 \mathrm{c}$.

Гак 1965 - Гак В. Г. Десемантизация языкового знака в аналитических структурах синтаксиca // Аналитические конструкции в языках различных типов. М.: Наука, 1965. С. 129143.

Жирмунский 1963 - Жирмунский В. М. Об аналитических конструкциях (1963) // Жирмунский В. М. Общее и германское языкознание. Л.: Наука, ЛО, 1976. С. 82-125.

Кацнельсон 1948 - Кацчнельсон С. Д. О грамматической категории // Вестник ЛГУ, 1948. № 2. C. 114-134.

Кацнельсон 1986 - Каџнельсон С. Д. Общее и типологическое языкознание. Л.: Наука, 1986. $297 \mathrm{c}$.

Крылов 2004 - Крылов С. А. Теоретическая грамматика современного монгольского языка и смежные проблемы общей лингвистики. Часть 1. Морфемика, морфонология, элементы фонологической трансформаторики (в аспекте общей теории морфологических и морфонологических моделей) М.: Вост. лит., 2004. 479 с.

Крылов 2012а - Крылов С. А. Структурно-вероятностная модель монгольского языка на базе Генерального корпуса современного монгольского языка // отв. ред. Дыбо А. В. Урало-алтайские исследования. 2012. № 1(6). С. 78-105.

Крылов 20126 - Крылов C. A. The general corpus of the modern Mongolian language and its structural-probabilistic model // гл. ред.Кибрик А. Е. Компьютерная лингвистика и интеллектуальные технологии: По мат-лам ежегодн. Междунар. конф. «Диалог» (Бекасово, 30 мая - 3 июня 2012 г.). Вып. 11 (18). М.: Изд-во РГГУ. 2012. С. 331-341.

Крылов 2013 - Крылов С. А. Опыт изучения современного монгольского языка в количественном освещении // Вопросы языкознания. 2013. № 5. С. 46-57.

Крылов 2014 - Крылов С. А. Теоретическая грамматика монгольского языка и смежные проблемы общей лингвистики: (в 6 ч.) Ч. 2. Структурно-вероятностная модель современного монгольского языка (на базе Генерального корпуса современного монгольского языка). М.: Наука; Вост. лит., 2014. $637 \mathrm{c}$.
Крылов и др. 2015 - Крылов С. А., Дыбо А. В. Шеймович $A$. B. Some possibilities of semantic and etymological tagging of corpora for turkic languages (=Некоторые возможности семантической и этимологической разметки для корпусов тюркских языков (расстановка семантических тэгов в электронном хакасско-русском словаре)) // Сб. тр. междунар. конф. TurkLang - 2015 (Turkic Languages Processing: TurkLang 2015). Казань, 2015. C. 304-327.

Крылов и др. 2016 - Крылов С. А., Дыбо А. В., Шеймович $A$. $B$. Расстановка семантических и деривационных тэгов в электронном хакасско-русском словаре // Российская тюркология. 2016. № 2. С. 28-39.

Крылов 2016 - Крылов С. А. О принципах синтаксического анализа в сводном корпусе монгольских языков // Гуманитарная наука Юга России: международное и региональное взаимодействие. Мат-лы II Междунар. науч. конф., посвящ. 75-летию Калмыцкого института гуманитарных исследований РАН (г. Элиста, 14-15 сент. 2016 г.) Элиста: КИГИ РАН, 2016. С. 198-199.

Крылов 2017а - Крылов С. А. Сочетаемость монгольских синтетических словоформ: количественный аспект // Вестник Калмыцкого института гуманитарных исследований PAH. 2017. № 4. C. 108-133.

Крылов 20176 - Крылов С. А. Монгольские аналитические конструкции в количественном аспекте // Вестник Калмыцкого института гуманитарных исследований РАН. 2017. № 5. С. 155-179.

Крылов 2017в - Крылов С. А. Монгольские аналитические словоформы: опыт лингвостатистического исследования // Куканова В. В. (отв. ред.). Вестник Калмыцкого института гуманитарных исследований РАН. 2017. № 6. С. 79-93.

Крылов 2018а - Крылов С. А. Опыт дистрибутивно-статистической классификации монгольских аналитических словоформ // Oriental Studies. 2018. № 2. C. 88-101.

Крылов 20186 - Крылов С. А. О гибридных жанрах словарей (на материале монгольского языка) // сост. Панина А. С. Востоковедные чтения 2018. Лексикология и лексикография. К 200-летию ИВ РАН. Тезисы докладов межинститутской науч. конф. (г. Москва, 4-6 апреля 2018 г.). М.: ИВ РАН, 2018. C. 33-34.

Крылов 2018в - Крылов С. А. О гибридных жанрах словарей (на материале монголь- 
ского языка) // отв. ред. Шаляпина 3. М., ред.-сост. Панина А. С. Труды Института востоковедения РАН. Вып. 19. Проблемы общей и востоковедной лингвистики: Лексикология и лексикография. М.: ИВ РАН, 2018. C. 156-165.

Маслов 1975 - Маслов Ю. С. Введение в языкознание. М.: Высшая школа, 1975. 328 с.

Маслов 1987 - Маслов Ю. С. Введение в языкознание. Учеб. для филол. спец. вузов. 2-е изд., перераб. и доп. М.: Высшая школа, 1987. $272 \mathrm{c}$.

Шайкевич 1990 - Шайкевич А. Я. Количественные методы в языкознании // Лингвистический энциклопедический словарь. М.: Советская энциклопедия, 1990. С. 231.

Шайкевич 2009 - Шайкевич А. Я. Количественные методы в языкознании // гл. ред. С. Л. Кравец. Большая Российская Энциклопедия. Т. 14 (Киреев - Конго). М.: Большая Российская Энциклопедия, 2009. С. 478.

Шайкевич и др. 2013 - Шайкевич А. Я., Андрющенко В. М., Ребеикая Н. А. Дистрибутивно-статистический анализ языка русской прозы 1850-1870-х гг. Т. 1. М.: Языки славянской культуры, 2013. 504 с.

Шайкевич и др. 2016 - Шайкевич $A$. Я., Андрющенко В. М., Ребецкая Н. А. Дистрибутивно-статистический анализ языка русской прозы 1850-1870-х гг. Т. 2. М.: Языки славянской культуры, 2016. 850 с.

Шаляпина 2007 - Шаляпина 3. М. Трехмерная стратификационная модель языка и его функционирования: к общей теории лингвистических моделей. М.: Вост. лит., 2007. $480 \mathrm{c}$.

Lehmann 1982 - Lehmann Ch. Directions for interlinear morphemic translations // Folia linguistica. 1982. Vol. 16. Pp. 199-224.

Meillet 1912 - Meillet, Antoine. L'évolution des formes grammaticales. Scientia (Rivista di scienza). 1912. Vol. XII. No. XXVI, 6. (Reprinted in: Meillet, Antoine. Linguistique historique et linguistique generale. Paris: Champion; Geneve: Slatkine, 1982. 335 p. (Pp.130-149)).

\section{References}

Gak V. G. Desemantization of a language sign in syntactical analytical constructions. In: [Analytical Constructions in Typologycially Different Languages]. Moscow: Nauka, 1965. Pp. 129-143. (In Russ.)

Katsnelson S. D. [General and Typological Linguistics]. Leningrad: Nauka, 1986. 297 p. (In Russ.)
Katsnelson S. D. Grammatical category revisited. Vestnik LGU. 1948. No. 2. Pp. 114-134. (In Russ.)

Krylov S. A. [Theoretical Grammar of Modern Mongolian and Related Issues of General Linguistics]. Vol. 1: 'Morphemics, Morphonology, Elements of Phonological Transformatorics'. Moscow: Vostochnaya Literatura, 2004. 479 p. (In Russ.)

Krylov S. A. [Theoretical Grammar of the Mongolian Language and Related Issues of General Linguistics]. In 6 vol. Vol. 2: 'A Structure-and-Frequency Model of Modern Mongolian'. Moscow: Vostochnaya Literatura, 2014. 637 p. (In Russ.)

Krylov S. A. A Consolidated Corpus of Mongolic Languages: Principles of Syntactical Analysis Revisited. [The Humanities in Souhern Russia: International and Regional Cooperation]. Conf. proc. (Elista; September 14-15, 2016). Elista: Kalmyk Humanities Research Institute of RAS, 2016. Pp. 198-199. (In Russ.)

Krylov S. A. A structure-and-frequency model of the Mongolian language on the basis of the General Corpus of Modern Mongolian. UralAltaic Studies. 2012. No. 1(6). Pp. 78-105. (In Russ.)

Krylov S. A. Compatibility of Mongolian synthetic word forms: a quantitative aspect. Bulletin of the Kalmyk Institute for Humanities of the RAS (Oriental Studies). 2017. No. 4. Pp. 108133. (In Russ.)

Krylov S. A. Hybrid genres of dictionaries revisited: a case study of the Mongolian language. In: [Oriental Studies Readings 2018]. Panina A. S. (comp.). Conf. proc. (Moscow; April 4-6, 2018). Moscow: Institute of Oriental Studies of RAS, 2018. Pp. 33-34. (In Russ.)

Krylov S. A. Mongolian analytical constructions: a quantitative perspective. Bulletin of the Kalmyk Institute for Humanities of the RAS (Oriental Studies). 2017. No. 5. Pp. 155-179. (In Russ.)

Krylov S. A. Mongolian analytical word forms: an effort of distributive and statistical classification. Oriental Studies. 2018. Vol. 36. Is. 2. Pp. 88-101. (In Russ.)

Krylov S. A. Mongolian analytical word forms: an effort of quantitative research. Bulletin of the Kalmyk Institute for Humanities of the RAS (Oriental Studies). 2017. No. 6. Pp. 79-93. (In Russ.)

Krylov S. A. On hybrid dictionaries, exemplified by Mongolian. In: [Institute of Oriental Studies of the RAS: Transactions]. Vol. 19: 'Issues of General and Oriental Linguistics: Lexicology 
and Lexicography'. Shalyapina Z. M. (ed.), Panina A. S. (ed., comp.). Moscow: Institute of Oriental Studies of RAS, 2018. Pp. 156-165. (In Russ.)

Krylov S. A. The General Corpus of the Modern Mongolian Language and its structuralprobabilistic model. In: Computational Linguistics and Intellectual Technologies. Conf. proc. (Bekasovo; May 30 - June 3, 2012). Vol. 11 (18). Moscow: Russian State University for the Humanities, 2012. Pp. 331- 341. (In Eng.)

Krylov S. A., Dybo A. V., Sheymovich A. V. A digital Khakass-Russian dictionary: semantic and derivative tagging. Russian Turkology. 2016. No. 2. Pp. 28-39. (In Russ.)

Krylov S. A., Dybo A. V., Sheymovich A. V. Some possibilities of semantic and etymological tagging of corpora for Turkic languages. In: Turkic Languages Processing: TurkLang 2015. Conf. proc. Kazan, 2015. Pp. 304-327. (In Eng.)

Krylov S. A. Investigating modern Mongolian: a quantitative perspective. Voprosy Jazykoznanija. 2013. No. 5. Pp. 46-57. (In Russ.)

Lehmann Ch. Directions for interlinear morphemic translations. Folia linguistica. 1982. Vol. 16. Pp. 199-224. (In Eng.)

Maslov Yu. S. [Introduction to Linguistics]. Moscow: Vysshaya Shkola, 1975. 328 p. (In Russ.)

Maslov Yu. S. [Introduction to Linguistics]. Textbook for university students. $2^{\text {nd }}$ ed., rev. and suppl. Moscow: Vysshaya Shkola, 1987. 272 p. (In Russ.)

Meillet, Antoine. Evolution of grammatical forms. Scientia (Rivista di scienza). Vol. XII. 1912.
No. XXVI, 6. (Reprinted in: Meillet, Antoine. [Historical and General Linguistics]. Paris: Champion; Geneve: Slatkine, 1982. 335 p. (Pp.130-149)). (In Fr.)

Shalyapina Z. M. [A Three-Dimensional Stratificational Model of the Language and Its Functioning: the General Theory of Linguistic Models Revisited]. Moscow: Vostochnaya Literatura, 2007. 480 p. (In Russ.)

Shaykevich A. Ya. Quantitative research methods in linguistics. In: [Encyclopedic Dictionary of Linguistics]. Moscow: Sovetskaya Entsiklopediya, 1990. P. 231. (In Russ.)

Shaykevich A. Ya. Quantitative research methods in linguistics. In: [Great Russian Encyclopedia]. Kravets S. L. (ed.). Vol. 14: 'Киреев Конго'. Moscow: Bolshaya Rossiyskaya Entsiklopediya, 2009. P. 478. (In Russ.)

Shaykevich A. Ya., Andryushchenko V. M., Rebetskaya N. A. [Russian Prose of 18501870s: Distributive-Statistical Analysis of Its Language]. Vol. 1. Moscow: Yazyki Slavyanskoy Kultury, 2013. 504 p. (In Russ.)

Shaykevich A. Ya., Andryushchenko V. M., Rebetskaya N. A. [Russian Prose of 18501870s: Distributive-Statistical Analysis of Its Language]. Vol. 2. Moscow: Yazyki Slavyanskoy Kultury, 2016. 850 p. (In Russ.)

Vinogradov V. V. [The Russian Language: (Grammatical Teaching of Word)]. Textbook for university students. Moscow; Leningrad: Uchpedgiz, 1947. 784 p. (In Russ.)

Zhirmunsky V.M. Anatytical constructions revisited (1963). In: Zhirmunsky V. M. [General and German Linguistics]. Leningrad: Nauka, 1976. Pp. 82-125. (In Russ.) 